\title{
Experimental evidence on biodiversity impacts of variable retention forestry, prescribed burning, and deadwood manipulation in Fennoscandia
}

\author{
Matti Koivula ${ }^{1}$ and Ilkka Vanha-Majamaa ${ }^{2^{*}}$ (D)
}

\begin{abstract}
Intensive forest management has been applied in most Fennoscandian forests for a period of almost one felling rotation. This paradigm has produced even-aged and even-structured forests of different successional stages that cover about $90 \%$ of forest land. At the same time, wildfires have been nearly eliminated in most of the Fennoscandian nature. Consequently, hundreds of species are red-listed because of forest management. To support these species, forest management requires improvements. Variable retention forestry and habitat restoration have been suggested to mitigate negative effects of forest management on biodiversity, and these have been practiced to some extent during the past few decades. Here, we review experimental results on the effects of variable retention and two restoration measures (prescribed burning and artificial addition of coarse woody debris) on different species groups in Fennoscandia. Our key findings are as follows: (i) Many species respond positively to felling within a few years, apparently due to released and often ephemeral resources, such as fresh residue and stumps. Species associated with shady conditions are negatively impacted, but any retention supports many of these, and their species composition remains almost unaffected with $50-70 \%$ retention of the initial tree volume. (ii) These effects remain detectable for at least 10-30 years or, according to some studies, nearly 100 years, e.g., in polypore fungi. (iii) Initial effects of prescribed burning on most species groups (apart from pyrophiles) are negative, but within 10-15 years post-fire sites begin to support many rare and threatened deadwood-dependent species. Epiphytic lichens, however, remain negatively affected. (iv) Artificial addition of deadwood (mostly high stumps) supports a wide spectrum of deadwood-dependent species, but the species composition differs from that of naturally died trees. (v) Moisture and micro-habitat variation are crucial for forest species at harvested sites, at least in forests dominated by Norway spruce. We conclude that felling method as such is of little importance for threatened forest species, although retention mitigates many negative effects. These species require microclimatic continuity, and maintenance and active increase of legacies, such as deadwood of different qualities (species, downed/standing, snag/log/stump, decay stage), very old trees, and tree species mixtures.
\end{abstract}

Keywords: Beetle, Forest management, Invertebrate, Polypore, Resilience, Resistance, Restoration, Saproxylic, Soil fauna, Understory vegetation

\footnotetext{
* Correspondence: ilkka.vanha-majamaa@luke.fi

${ }^{2}$ Natural Resources Institute Finland (Luke), Latokartanonkaari 9, FI-00790

Helsinki, Finland

Full list of author information is available at the end of the article
} 


\section{Background}

Intensive forest management, usually based on clear felling with site preparation and subsequent planting or seeding, followed by a few thinning operations during the rotation cycle, has been practiced in most of Fennoscandia (Finland, Norway, and Sweden) since the 1950s. Consequently, more than $90 \%$ of productive forest land in Finland and Sweden is structurally simplified, even-aged and even-structured (Gustafsson et al. 2010). Moreover, in Finland, less than 3\% of forest land area is protected or otherwise not available for wood production, whereas the remaining 97\% is available for wood production (Korhonen et al. 2016). Such large-scale implementation of intensive forest management has both short- and long-term effects on biodiversity.

Since the implementation of variable retention forestry (VRF) in the 1980s, it has become a common practice in many parts of the world, with usually rather modest retention, but occasionally the levels may be $30-40 \%$ (Beese et al. 2019; Scott et al. 2019). In Russia, for example, felling operations have been accompanied by such high levels of retention already since the early twentieth century (Shorohova et al. 2019). Effects of VRF on biodiversity have been studied in several experiments, first in North America (e.g., Beese et al. 2019), but later on also in Fennoscandia (Kuuluvainen and Grenfell 2012; Koivula et al. 2014). Although conventional clear felling is increasingly often replaced with alternative felling methods in Fennoscandia, it is still the prevailing regeneration felling method, usually combined with up to $3 \%$ of retention (proportion of the volume of living trees), i.e., about ten retention trees per ha (Kuuluvainen et al. 2019). It is notable that Fedrowitz et al. (2014) consider such low-level retention $(<2 \%)$ as clear felling and not VRF.

According to Fennoscandian red lists, based on IUCN criteria, nearly one-third of threatened species live in forests (Kålås et al. 2010; ArtDataBanken 2015; Hyvärinen et al. 2019). Hence, actions carried out especially in commercial forests are important for maintaining forest biodiversity in Fennoscandia.

Unlike most of the boreal region, forest fires have not been a major disturbance in recent decades in Fennoscandia. In Finland, for example, the annual burned area has declined steeply during the past hundred years, mainly because of effective fire detection and suppression, and forest management (Lindberg et al. 2020). The latter includes dense forest road network, small forest stands, thinning operations, and intentional removal of dead or damaged and deciduous trees. Therefore, introduction of prescribed burning has been recommended as a conservation and management measure (e.g., Kotiaho et al. 2015; Kontula and Raunio
2018; Äijälä et al. 2019; Hyvärinen et al. 2019). Research on ecological effects of prescribed burning has been carried out for several decades, whereas burning combined with VRF is a more recent topic. An overall review of the effects of prescribed burning has thus far been missing.

Prescribed burning increases habitat for pyrophilous species, but it also creates a rich pulse of dead wood, a crucial resource for thousands of species in Fennoscandia (e.g., Esseen et al. 1997; Siitonen 2001). Current management guidelines also commonly recommend to retain and actively create dead wood in harvesting operations (Anonymous 2019a). However, according to the national forest inventories in Finland, the average amount of dead wood has not increased since the 1990s; on the contrary, this number has declined rather steeply in northern Finland, from about 9.5 to the current $7 \mathrm{~m}^{3} \mathrm{ha}^{-1}$ (Anonymous 2016). This pattern is important as the maintenance of biodiversity depends on this resource: hundreds of Fennoscandian species are threatened because of the shortage of dead wood (Kålås et al. 2010; ArtDataBanken 2015; Hyvärinen et al. 2019).

In this paper, we review the main findings of experiments assessing the ecological impacts of VRF and restoration operations (here, prescribed burning and manipulation of coarse woody debris, CWD) on different species groups. With experiments, we refer to felling or restoration operations that were done in a replicated manner to isolate particular mechanisms that potentially affect biodiversity, thus excluding ad hoc comparisons of, e.g., differently treated stands. We focus on Fennoscandia but exclude its Russian part, as this has been discussed in Gustafsson et al. (2020). However, as we are aware of relevant papers from the Baltic countries (notably Estonia), we expand the geographic focus accordingly. Thus, unless specified otherwise, below we refer to Estonia, Finland, Norway, and Sweden as Fennoscandia for brevity.

Experiments allow powerful assessments of biological impacts for at least three reasons: species community composition before operations is often known, which increases the reliability of results; operations are done similarly at multiple locations, providing a quantification of site-to-site variation of impact; and unharvested reference (or control) forests are included in the same site type and area as the treatments. Despite these strengths, however, compilations of experimental results have thus far been missing.

\section{History of VRF and restoration experiments in Fennoscandia}

Due to rising concerns about losing old-growth forest species, retention of a few trees in clear felled stands started to become part of Fennoscandian forest management in the 1980s, with retention of aspen trees 
(Populus tremula). Growing interest in harvesting methods other than clear felling resulted in the first VRF experiments with biological sampling, NaturKultur and Härjedalen, in 1989 in Sweden to study selection felling. Variants of selection felling have since been assessed in several experiments (Table 1 ).

In the 1990s, several forest management experiments were established both in Finland and in Sweden, such as MONTA, RETREE, Snöberget, and MedelpadÅngermanland (Table 1). Many of these had been established to compare different forest management options and their biodiversity effects. Meanwhile, also restoration became a popular research topic. The first biodiversity-oriented trials on prescribed burning, combined with a significant amount of retention, were established in 1989 in the Patvinsuo national park, eastern Finland, in 1990 in Haraldstjärn, Älvdalen, central Sweden, and in 1992 in the Evo area, southern Finland (Wikars 1995; Penttilä and Kotiranta 1996; Penttilä et al. 2013). However, these trials had only 1-2 site replicates and no intentional, untreated reference sites. Therefore, experiments such as FIRE, EVO, and Future Forest were established in the early 2000s to study the combined effects of VRF and prescribed burning in both Scots pine-dominated and Norway spruce-dominated forests. In FIRE, retention level varied, whereas in EVO constant dispersed retention was combined with manipulated amount of downed deadwood, and Future Forest assessed gap felling accompanied with so-called high stumps (1-5 $\mathrm{m}$ tall artificial snags), cut using a harvester or a chain saw. High stumps have been studied also in, for example, the Fagerön and Spruce CWD (Sweden), MONTA (Finland), and Hedmark (Norway) experiments (Table 1 ).

The scope of research has recently been expanded from stand to landscape level. The DISTDYN experiment was established in Finland in 2009, followed by the Effaråsen experiment in Sweden in 2012. The idea in DISTDYN is to treat forested landscapes (not just stands) with varying felling methods and levels of retention (10\% or $50 \%$ in felled patches, including living and intentionally killed trees). Effaråsen applies 3\%, 10\%, 30\%, $50 \%$, and $100 \%$ retention, also including living and intentionally killed trees, and prescribed burning (Table 1).

In the following, the main findings of Fennoscandian experiments are discussed for both short- and long-term effects. In the current forest management, the prevailing practice in Finland is to retain about ten trees per hectare, usually in groups, in clear cuts as required by the Programme for the Endorsement of Forest Certification (pefc.org). We refer to this as "standard retention" below. Moreover, with "short term" we refer to the first three post-harvest years (the usual funding period of academic sources), whereas with "long term" we refer to longer follow-ups. The oldest Fennoscandian VRF experiments are from late-1980s or mid-1990s, which defines the upper limit for experimentally assessed postharvest processes. We summarize results for different species groups, beginning with short- and long-term responses to retention, and ending with prescribed burning, manipulations of CWD, and possible other important aspects, particularly soil moisture and site preparation. Finally, we discuss these results together with chronosequence studies and ad hoc comparisons on felling and restoration, to define recommendations for a better maintenance of biodiversity in managed forests.

\section{Publication search, and included experiments}

We first sought experiments using the Northern European Database of Long-Term Forest Experiments (noltfox.metla. fi, Karlsson 2008). We then continued this search, and expanded it to experiment-based publications, by using Web of Science and Scopus (30 September 2019). We used the following search-term thread: forest* AND (Finland OR Sweden OR Norway OR Estonia OR Latvia OR Lithuania) AND (logg* OR fell* OR harvest* OR cut* OR select* OR thinn* OR gap OR deadwood OR dead wood OR fire OR burn* OR restor* OR stump*) AND (plant* OR moss* OR lichen* OR polypor* OR fung* OR beetle* OR insect* OR diversit*). After pruning the initial set of papers down to relevant ones, we complemented the search by using first and senior author names and reference lists of the detected papers (Additional file 1: Table S1).

Below, we review the results of Fennoscandian forest management experiments containing biological sampling (Table 1, Fig. 1). All experiments compare VRF or restoration approaches to unharvested reference forests ("control") and often also clear felling without retention. The most commonly assessed methods are retention of up to about $50 \mathrm{~m}^{3} \mathrm{ha}^{-1}$, usually in a few groups of trees, and selection felling (Fig. 2). The latter can aim at an uneven age structure of trees, selective removal of the largest trees, or ordinary commercial thinning (Table 1). The RETREE and Medelpad-Ångermanland projects assessed retention patches of about $0.01-0.60$ ha in size, while patches have been smaller in the other experiments. Gap felling has thus far been studied in four experiments; the gaps are usually smaller than 0.2 ha, except in DISTDYN with gaps $0.1-0.3$ ha, the largest (diameter 50-60 m) being sometimes referred to as patch (or partial clear-cut) felling.

Deadwood can be artificially added in many ways to increase CWD for saproxylic (deadwood dependent) organisms; most often artificial CWD substrates are high stumps (Fig. 2). Since the mid-1990s, high stumps have become common elements of Fennoscandian forest management experiments. Other ways to increase deadwood-apart from burning trees-are less common: in 


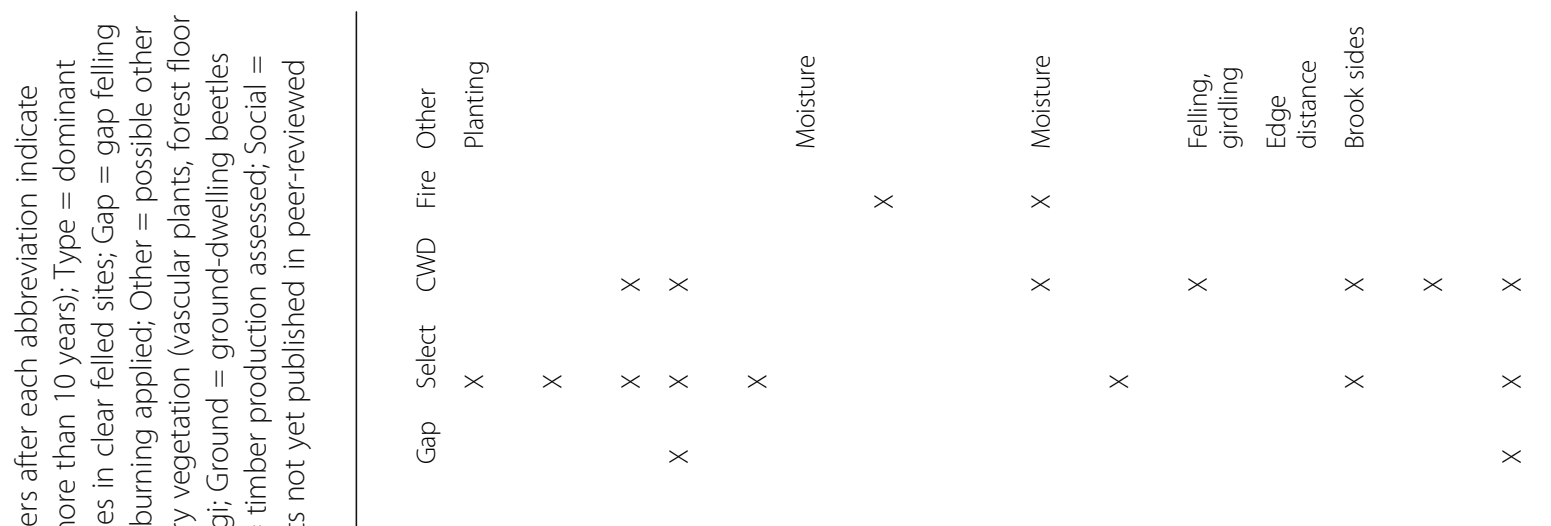

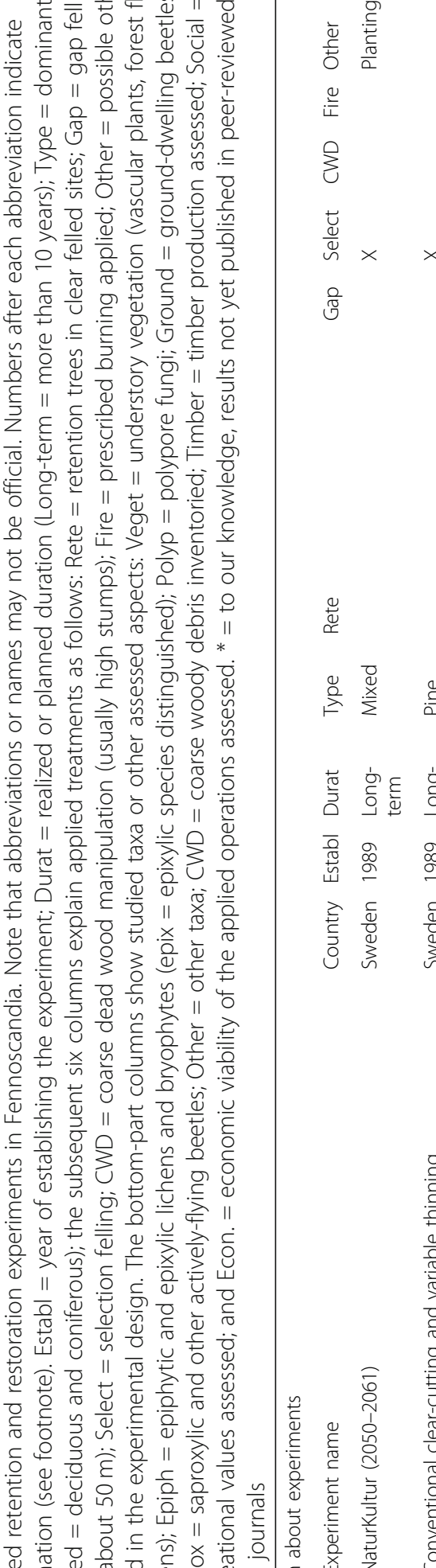

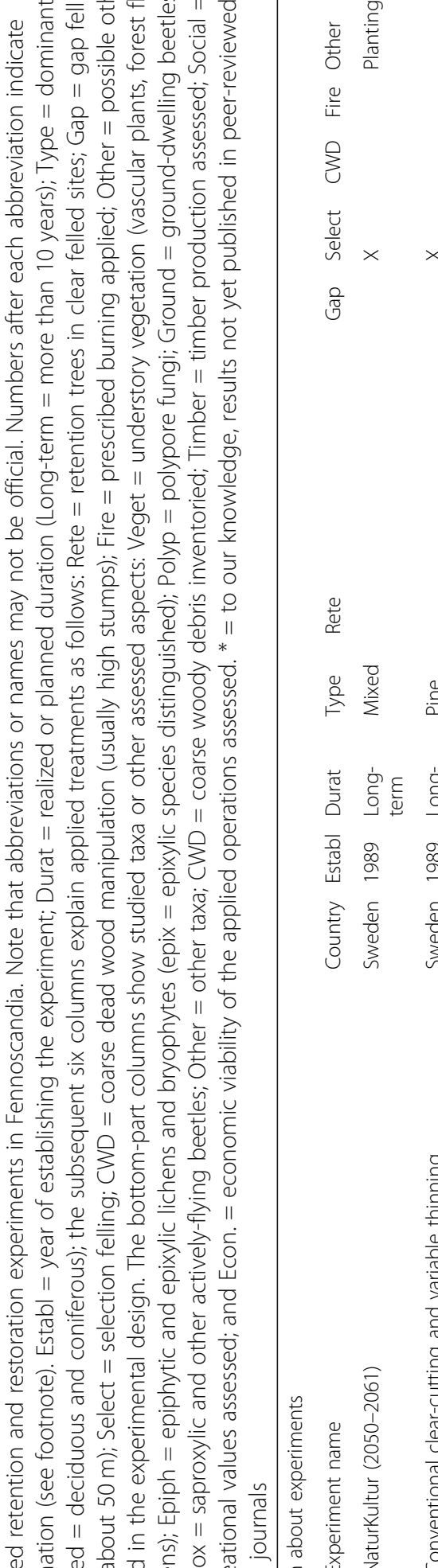

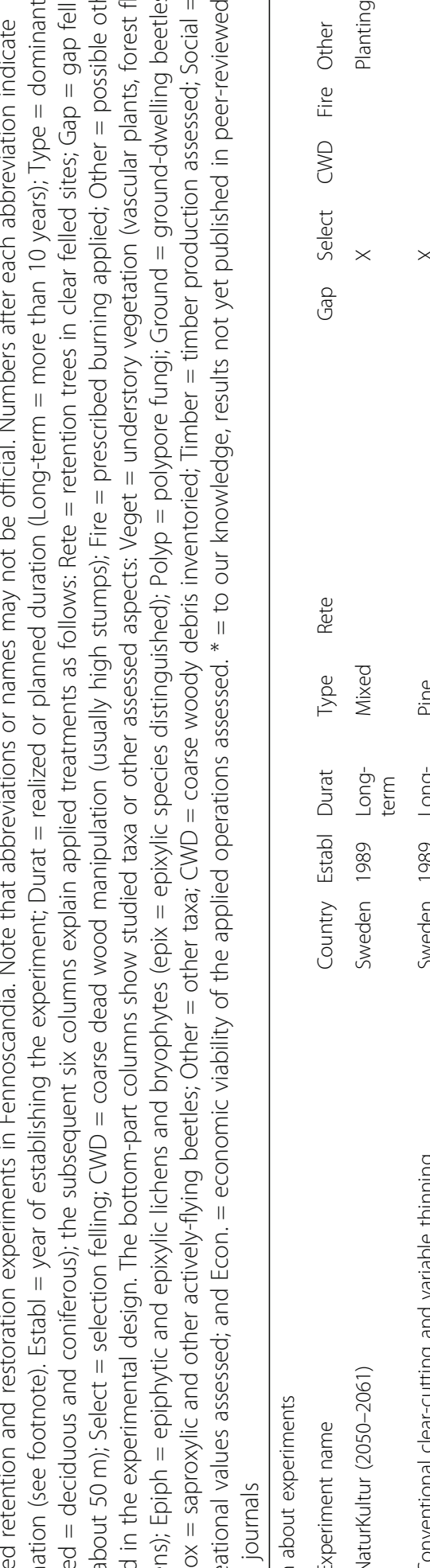

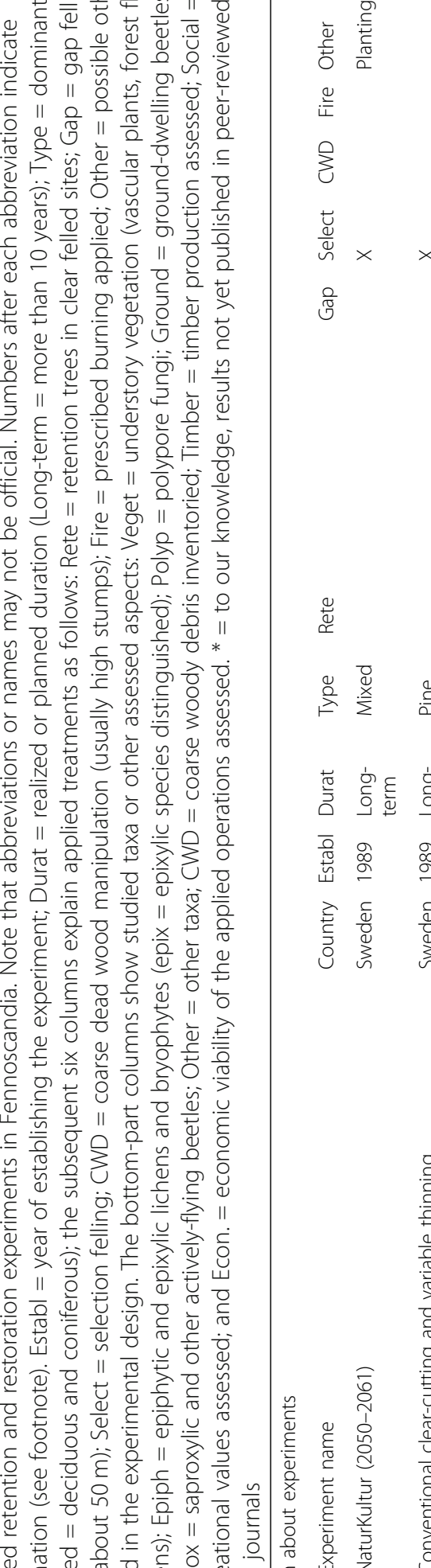

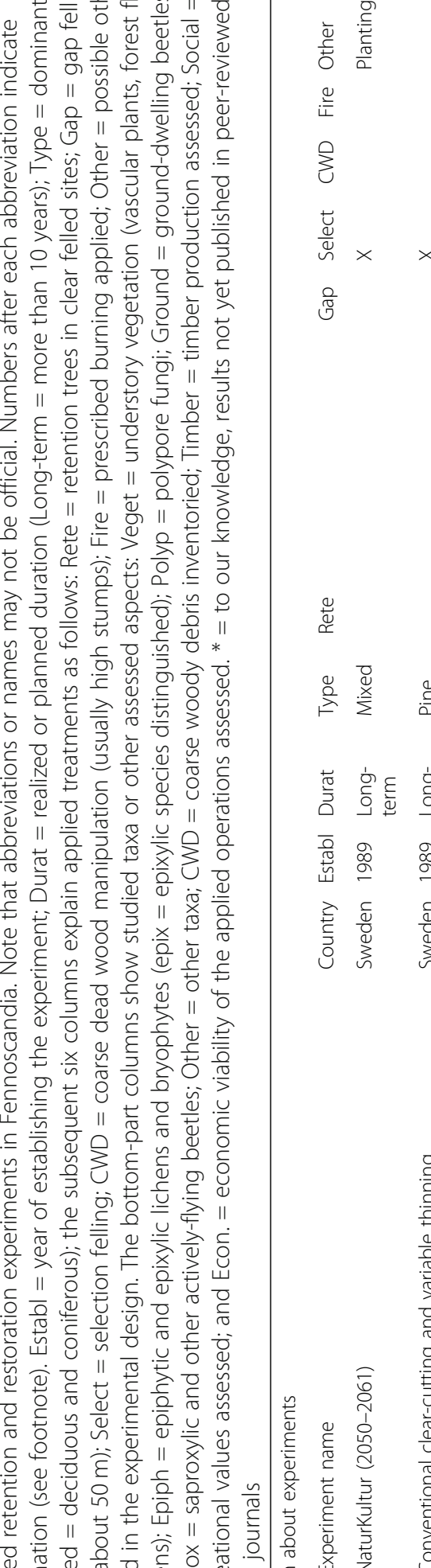

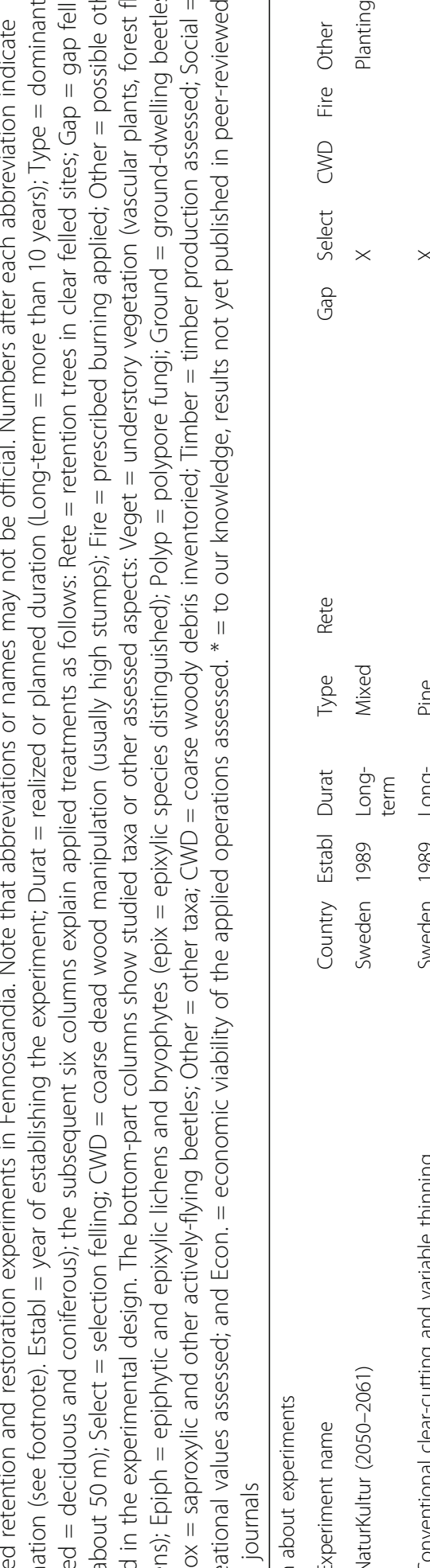

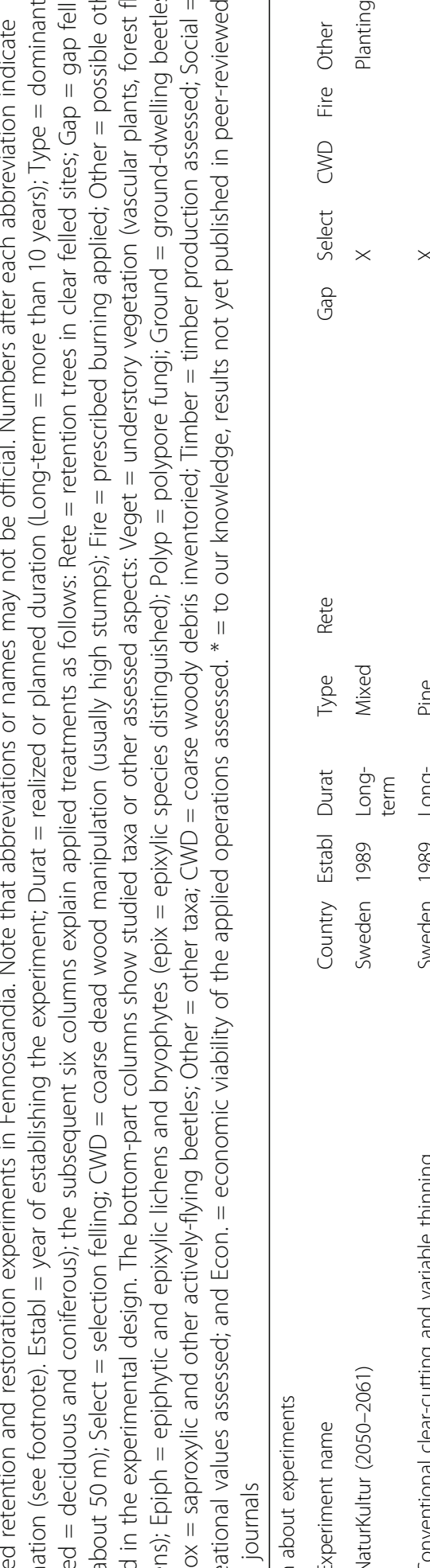

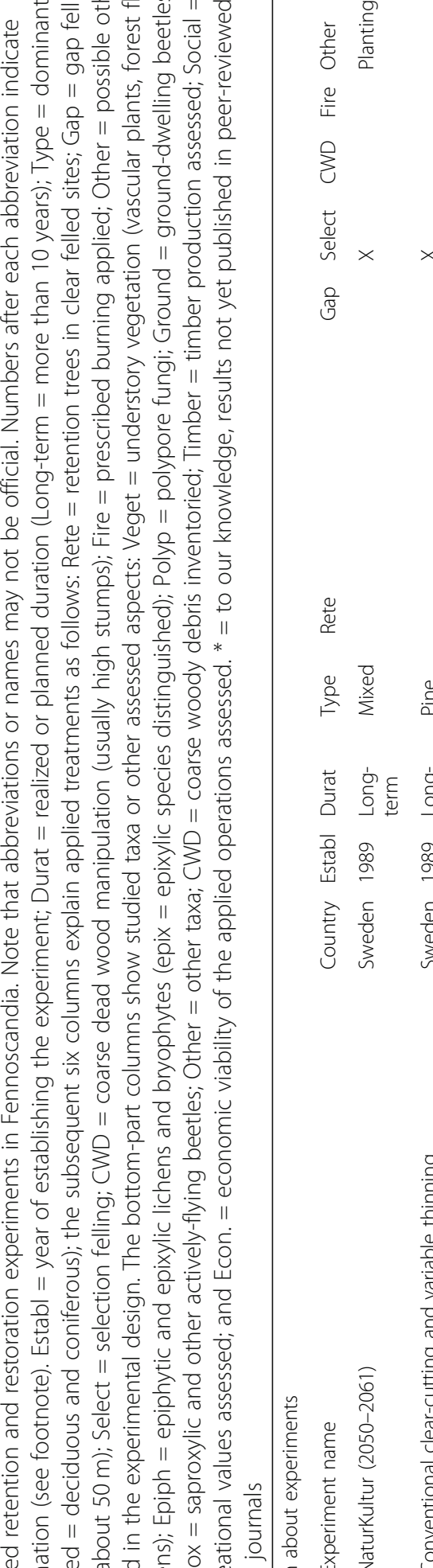

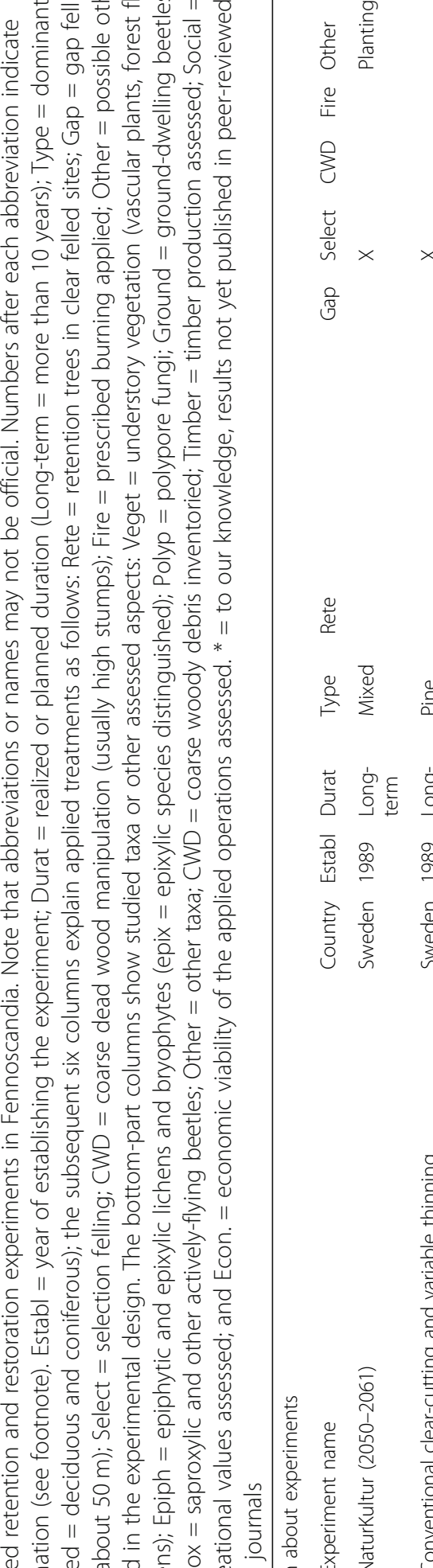

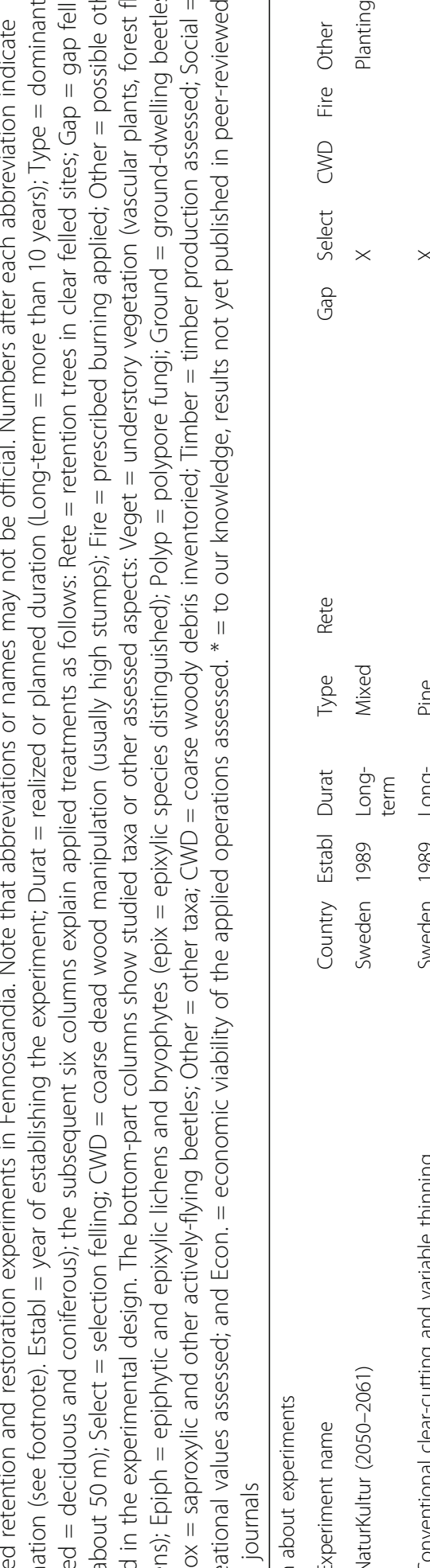

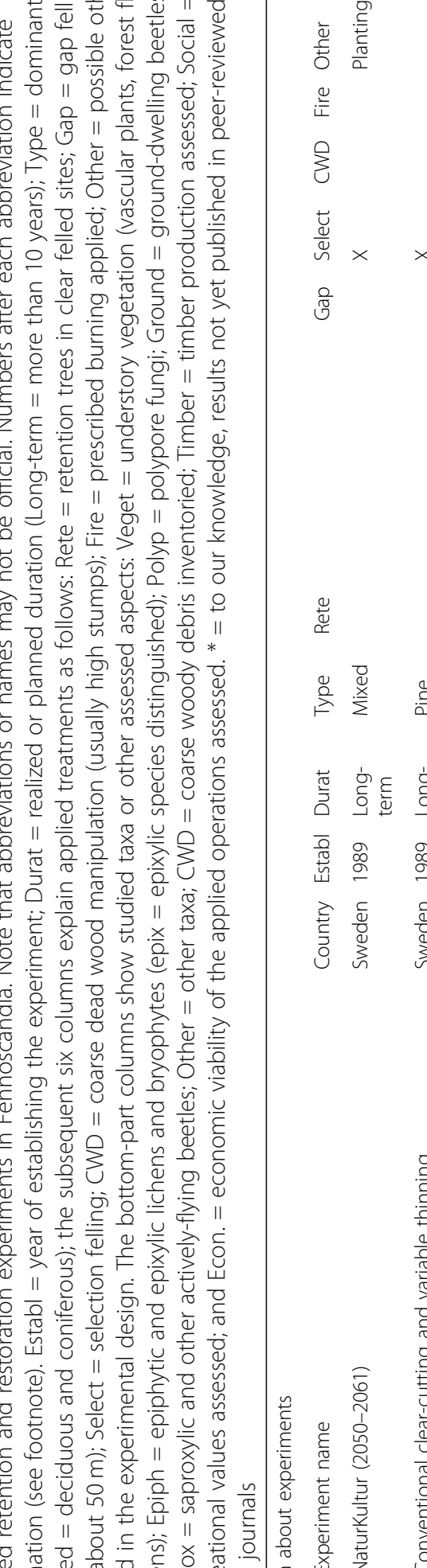

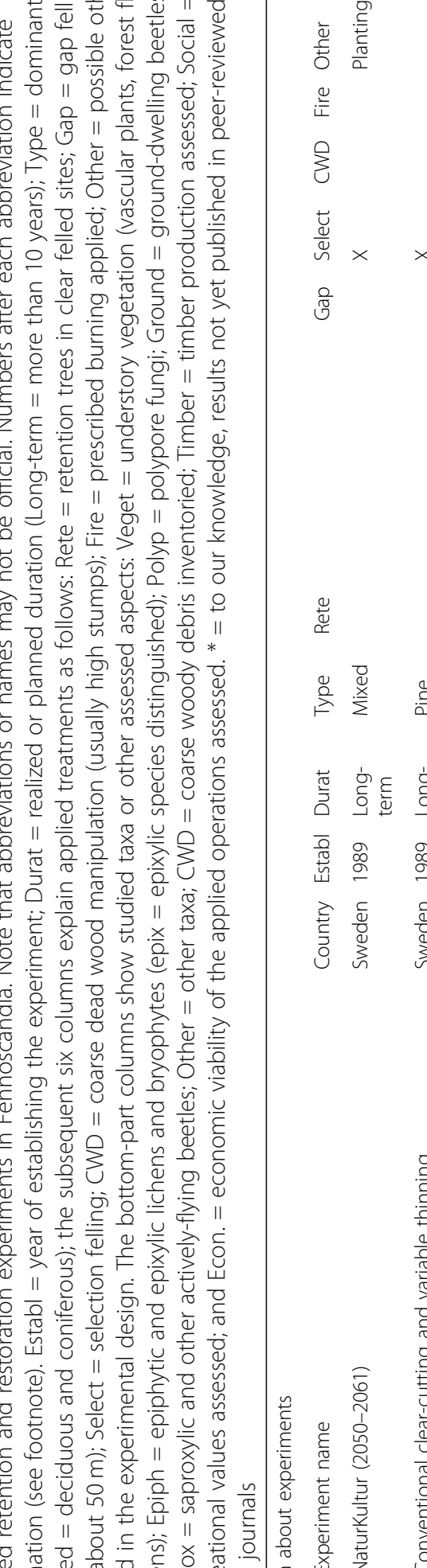

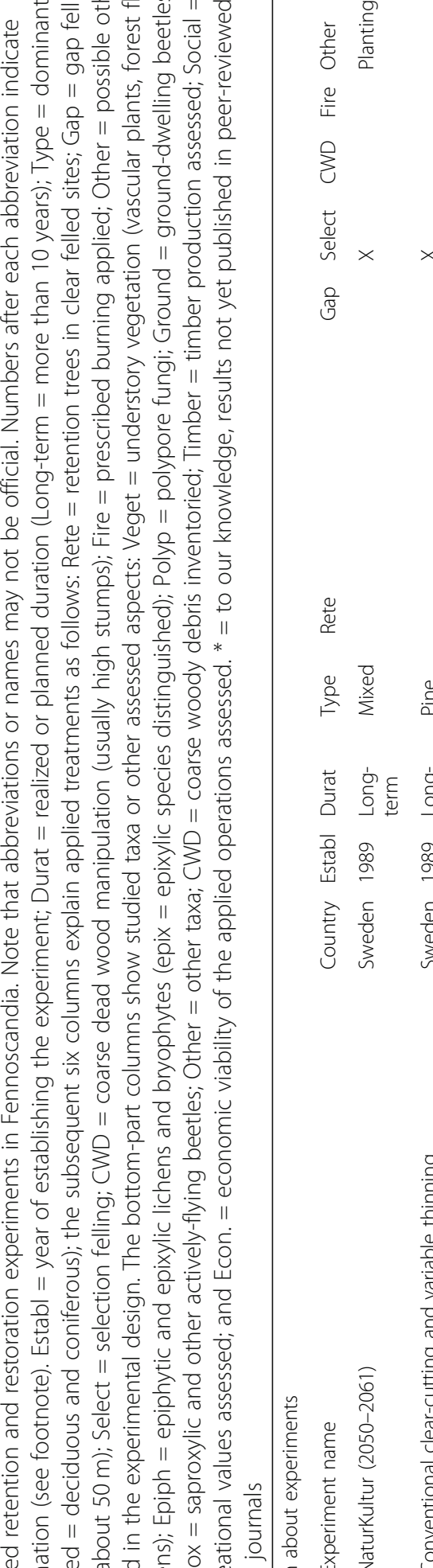

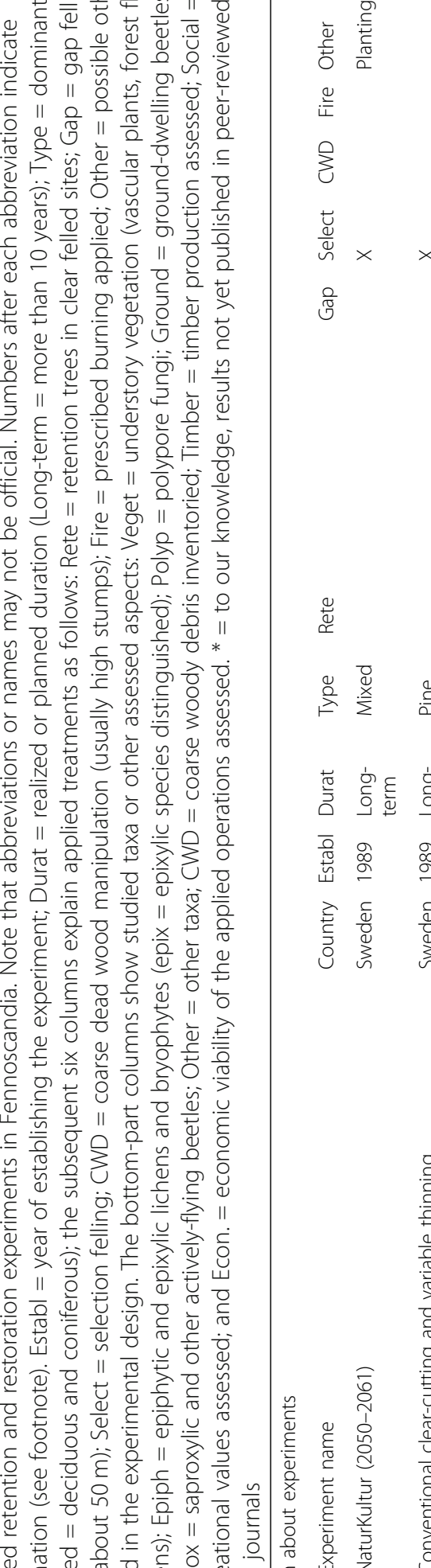

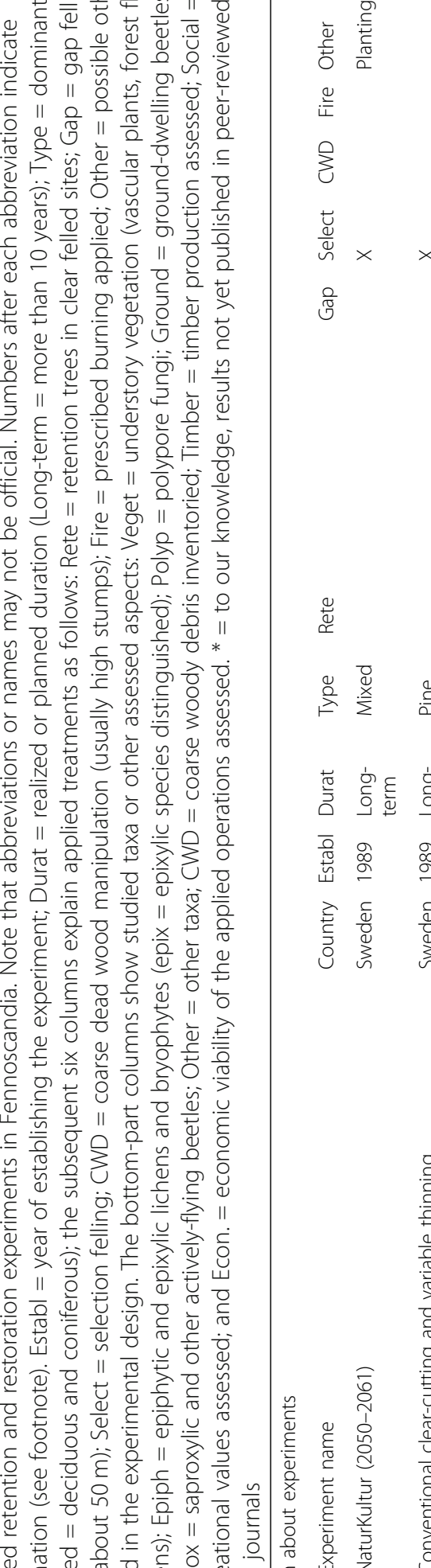

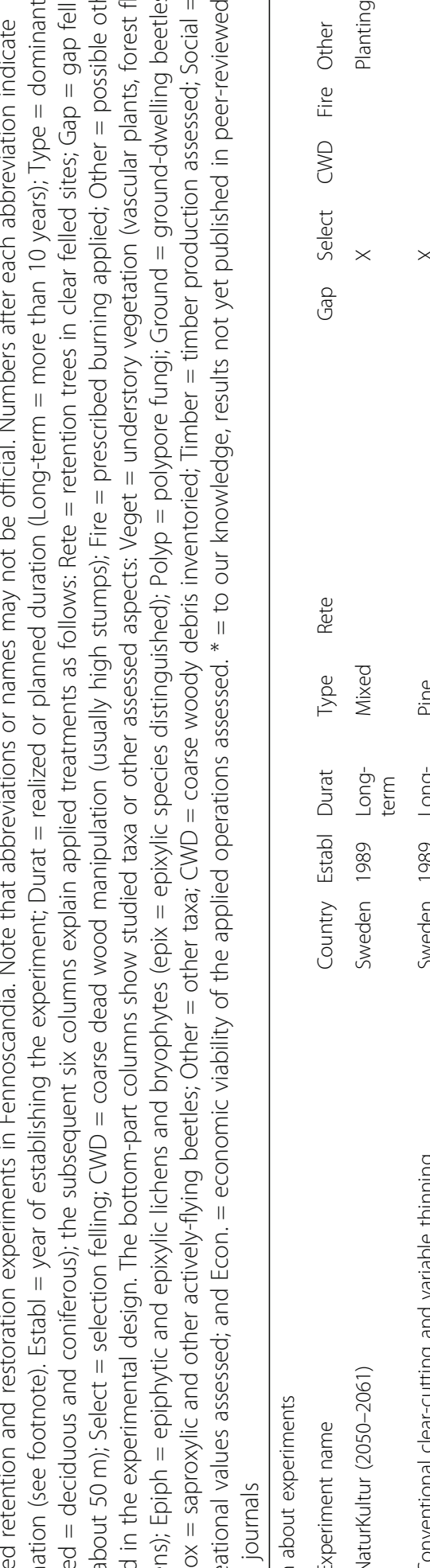

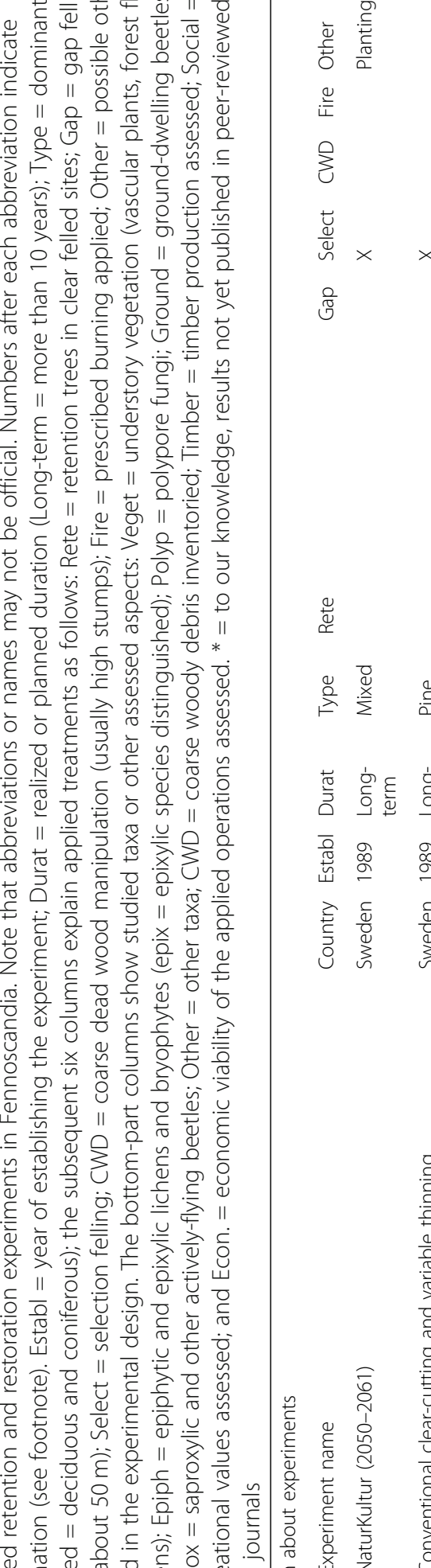

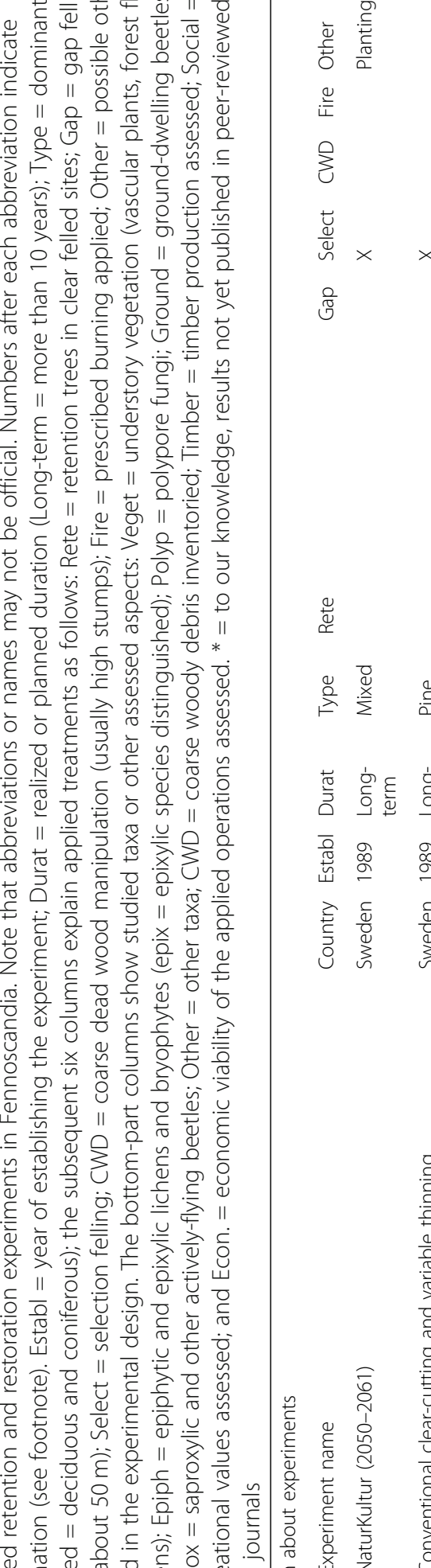

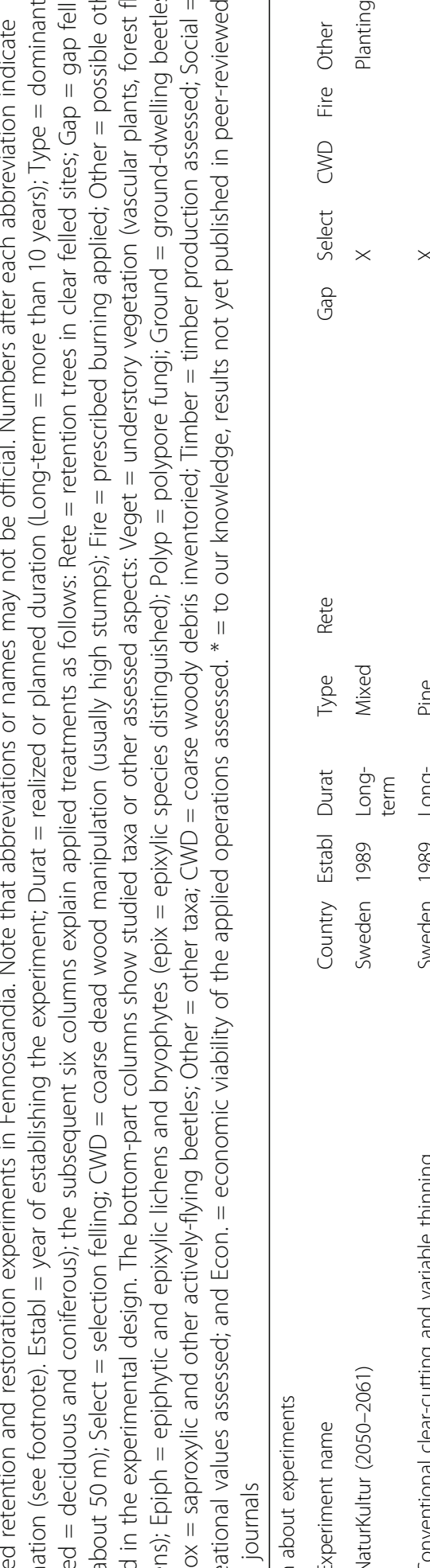

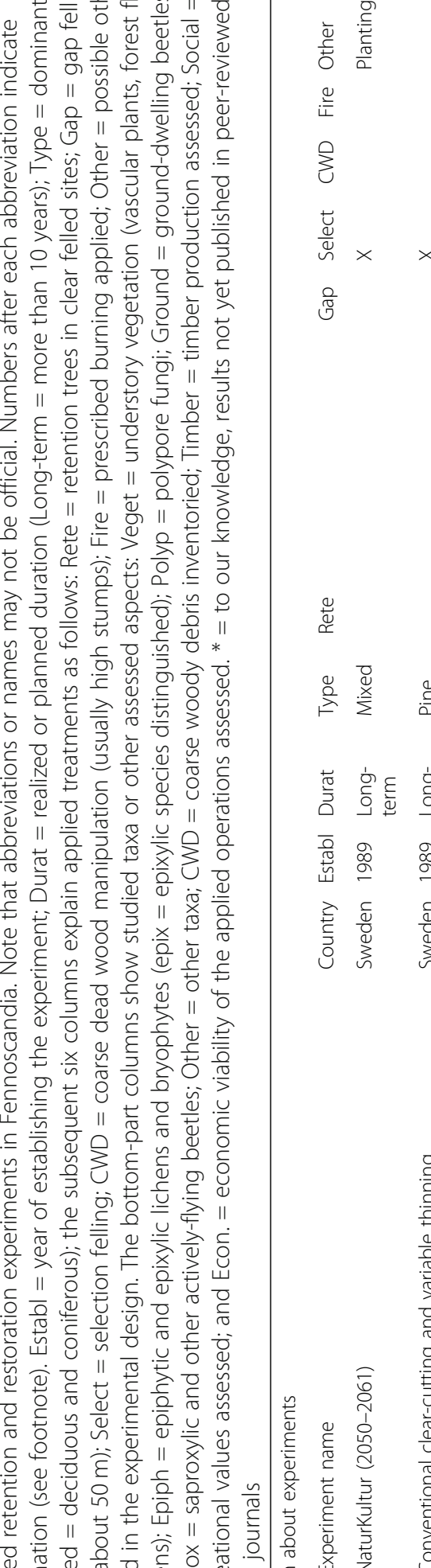

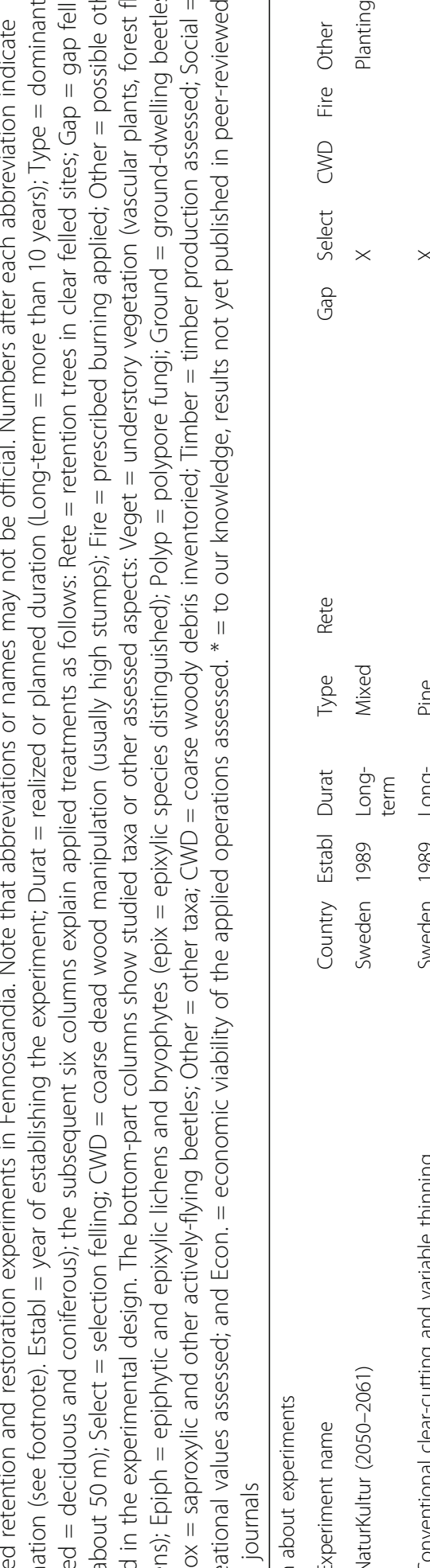

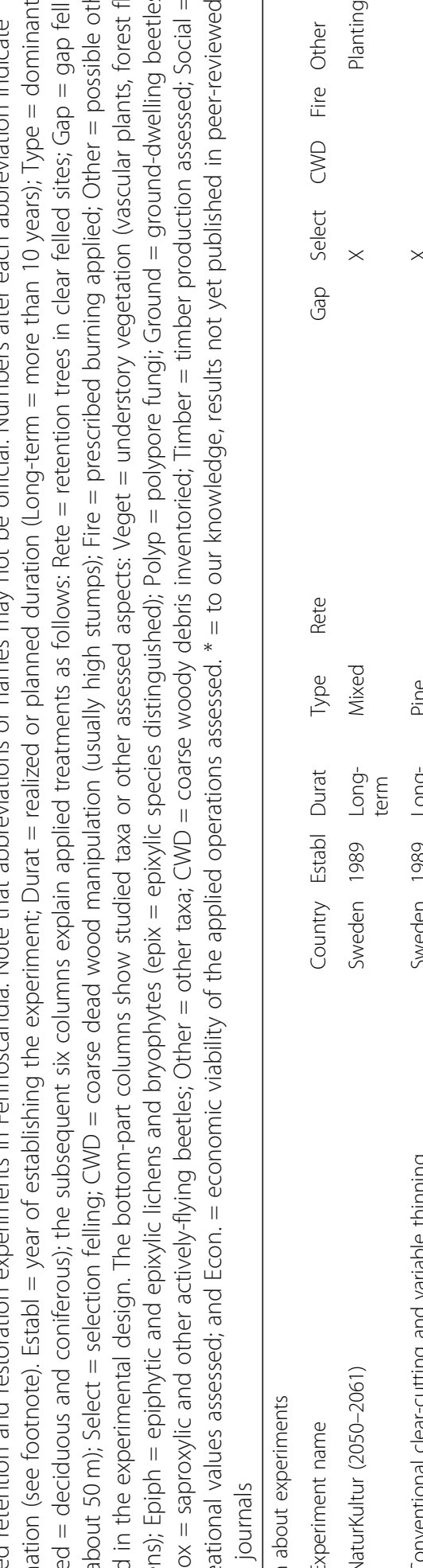

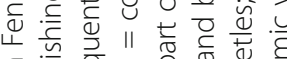

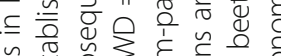

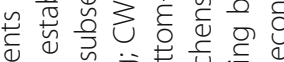
है

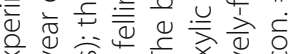

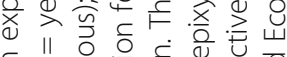

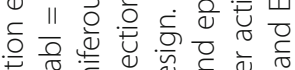

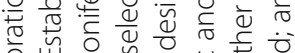
山 0 U 0

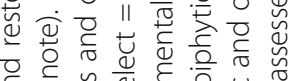
它

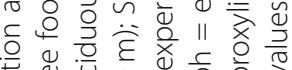

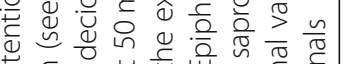

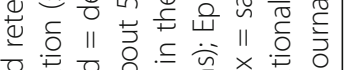

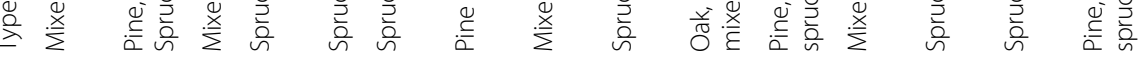

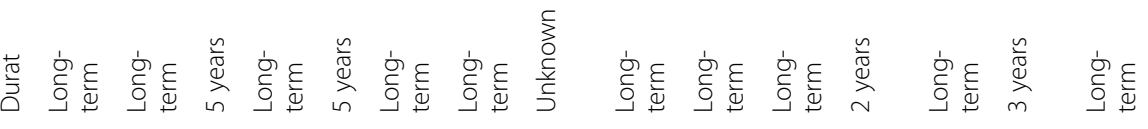

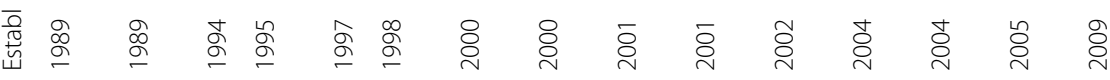

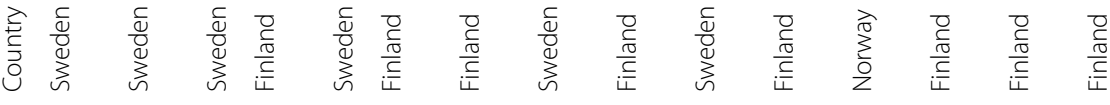

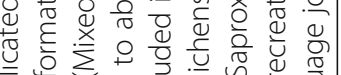

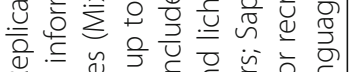

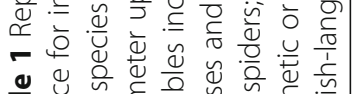

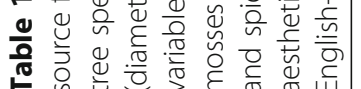
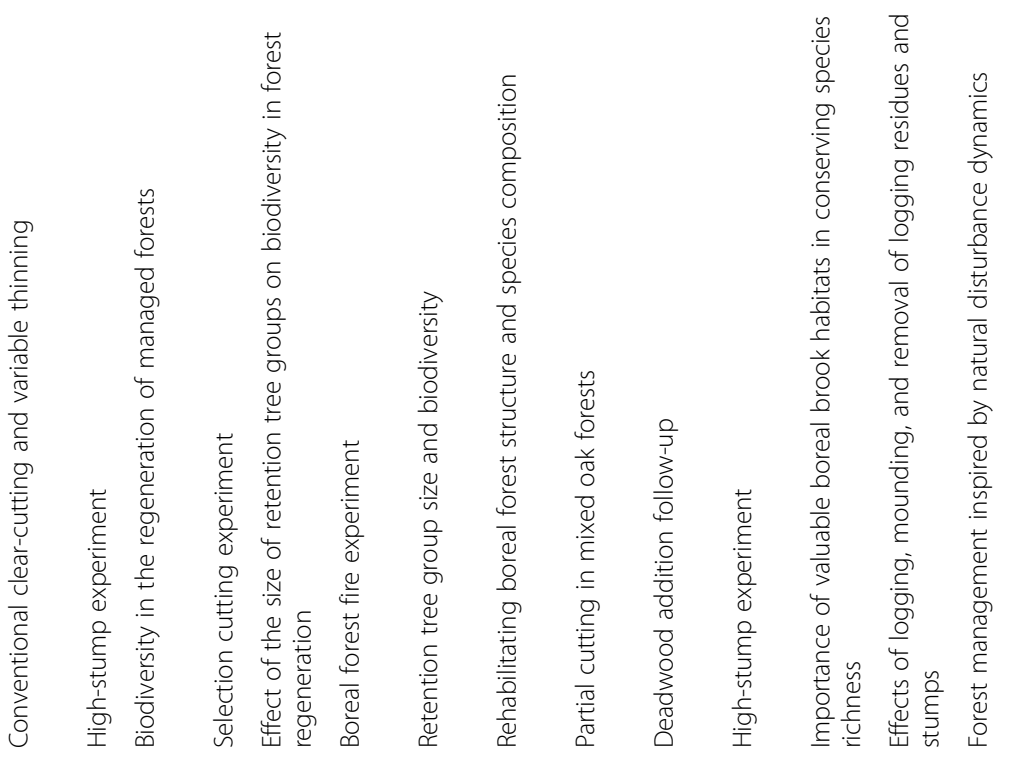
In

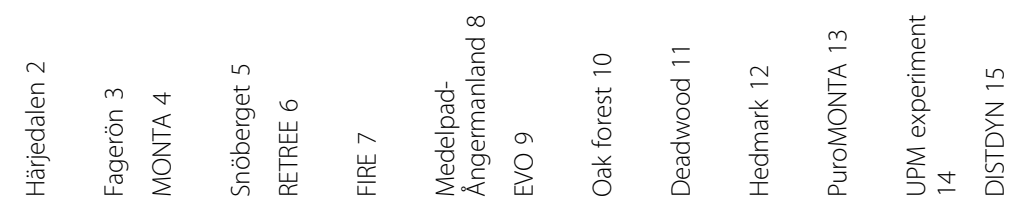




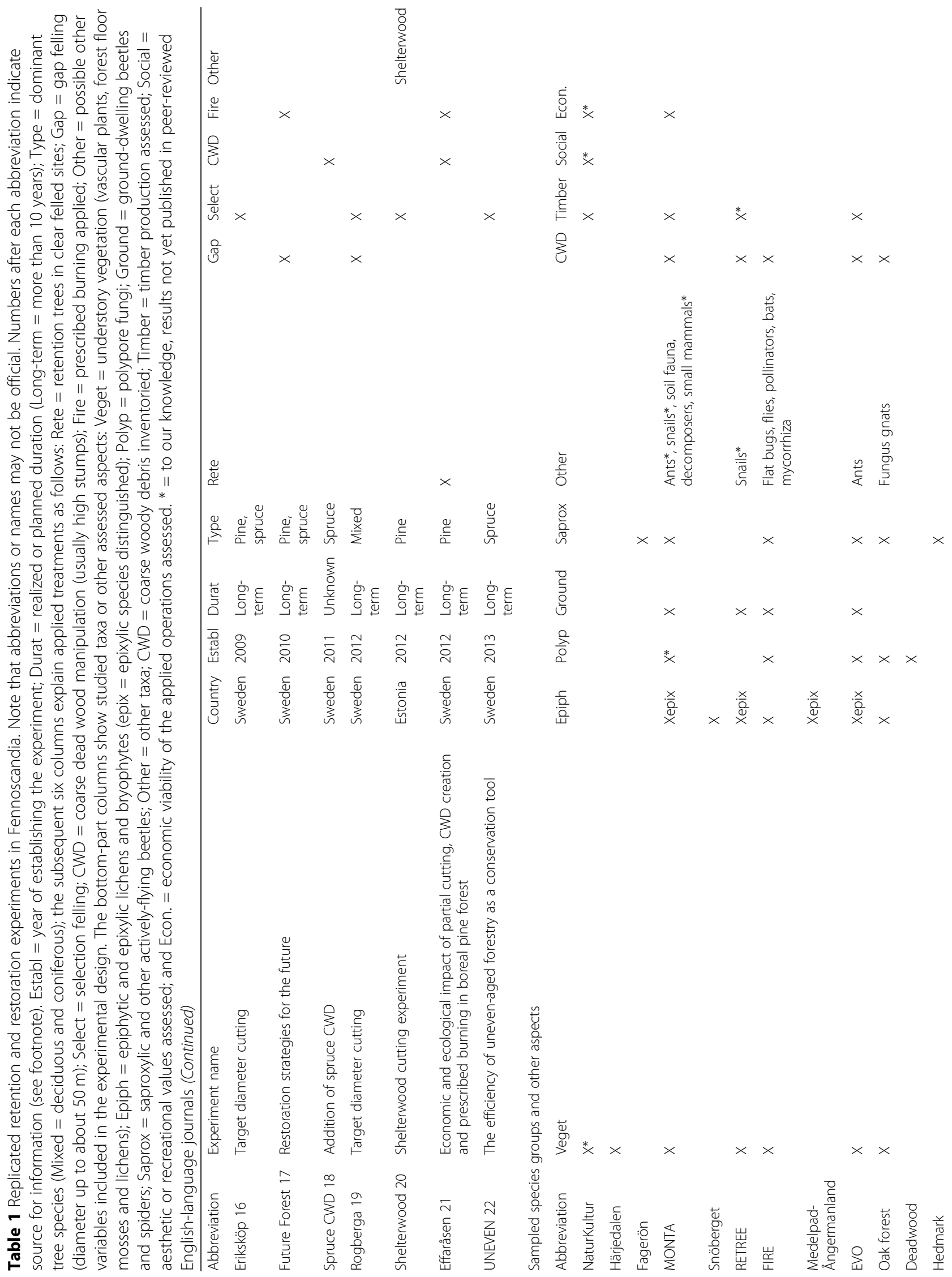




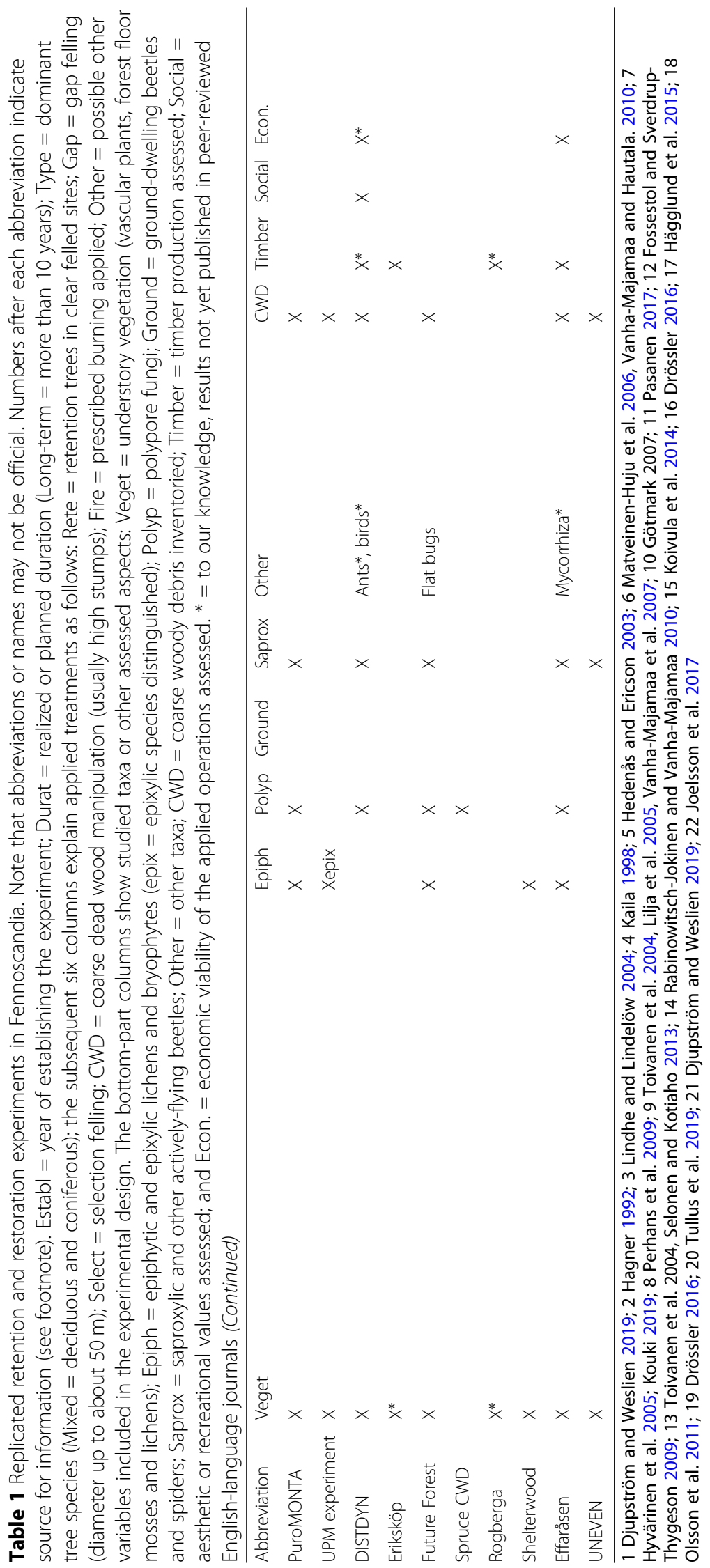




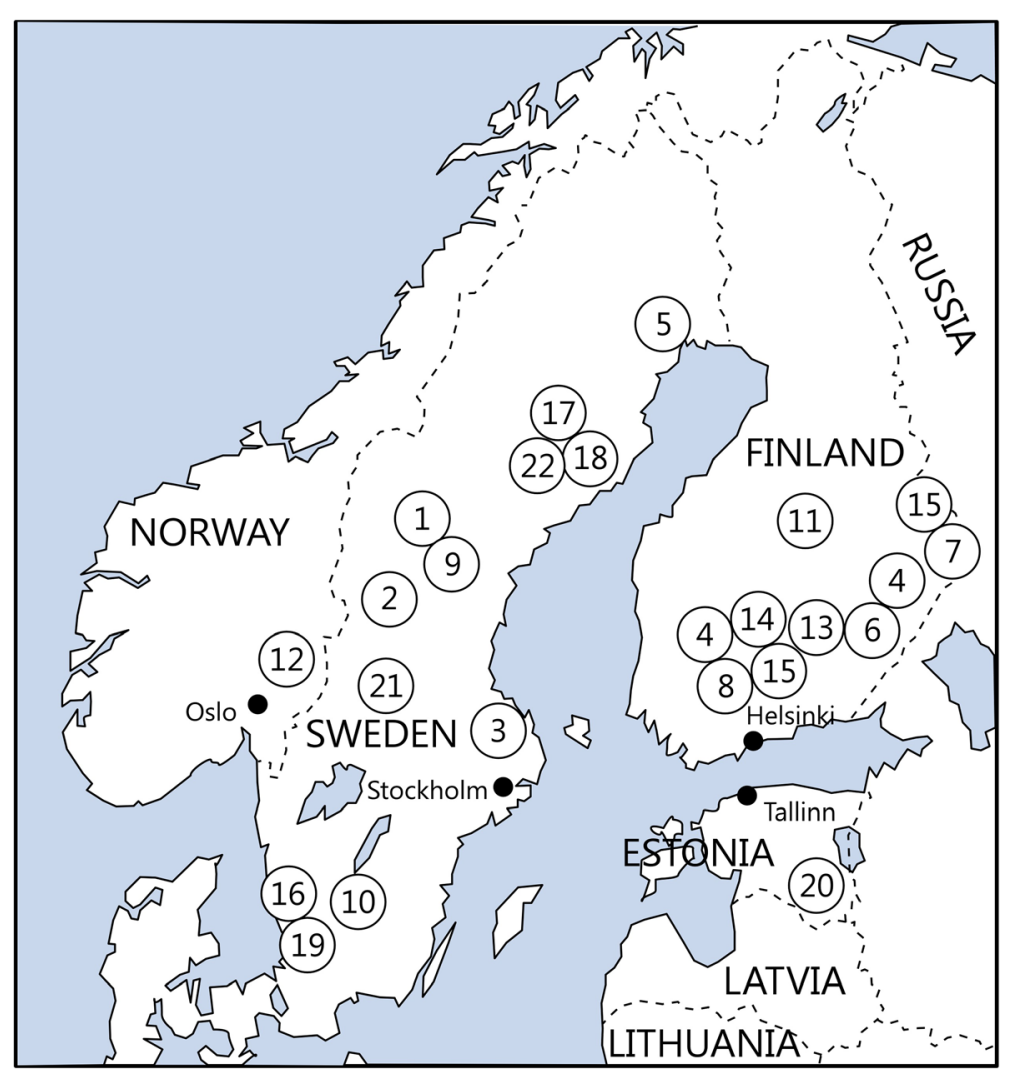

Fig. 1 Geographic locations of reviewed experiments (compare Table 1). Numbers refer to experiments as follows: 1 NaturKultur; 2 Härjedalen; 3 Fagerön; 4 MONTA (western and eastern areas); 5 Snöberget; 6 RETREE; 7 FIRE; 8 EVO; 9 Medelpad-Ångermanland; 10 Oak forest; 11 Deadwood (30 sites spread over S and C Finland); 12 Hedmark; 13 PuroMONTA; 14 UPM experiment; 15 DISTDYN (western and eastern areas); 16 Eriksköp; 17 Future Forest; 18 Spruce CWD; 19 Rogberga; 20 Shelterwood; 21 Effaråsen; 22 UNEVEN. Jittering was applied to avoid symbol overlaps

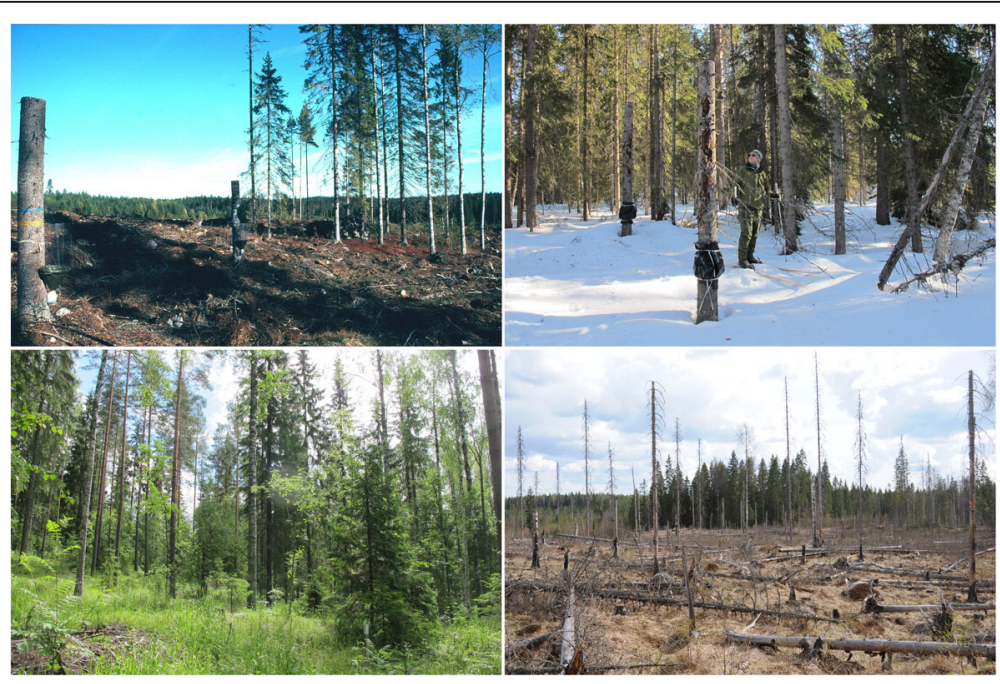

Fig. 2 Examples of practical retention and restoration. Top-left: retention tree group and high stumps in a clear-cut, first post-harvest summer (MONTA experiment, Finland, June 1996). Top-right: gap felling combined with high stumps, third post-harvest winter (Future Forest experiment, Sweden, March 2013). Bottom-left: selectively-felled mixed uneven-aged forest, third post-harvest summer (DISTDYN experiment, Finland, June 2012). Bottom-right: combined prescribed burning and intentionally killed, pushed-down trees at and around a paludified patch, seventh postharvest summer (EVO experiment, Finland, May 2009). Photos @ Matti Koivula 
the EVO experiment, CWD was created by felling 5,30 , or $60 \mathrm{~m}^{3} \mathrm{ha}^{-1}$ of trees, and another $50 \mathrm{~m}^{3} \mathrm{ha}^{-1}$ of standing trees was retained in a dispersed manner (Fig. 2). In the Deadwood addition follow-up in Finland, CWD was created by felling or girdling (Table 1 ).

Prescribed burning was first applied in a replicated manner in the FIRE experiment, followed by EVO and Future Forest. RETREE and EVO study sites, on the other hand, were established at and around paludified patches that are fairly common in spruce forests (Fig. 2). The idea in such placing was to assess possible interactions between within-site variation and felling (and burning in EVO), and whether such patches could act as "life boats" for species occupying shady or wet forests.

The studied species groups vary according to the experiment due to resource limitations, and a large part of the collected material still remains unanalyzed or unpublished (Table 1). Nearly all experiments with biological sampling have assessed understory vegetation (at least vascular plants). Invertebrates have thus far been sampled in 12 experiments; beetles have been sampled most frequently using flight-intercept window traps or pitfall traps, but also spiders, flat bugs (Heteroptera: Aradidae), soil invertebrates, and land snails have been sampled in some experiments. Data on lichens, mosses, liverworts (both forest-floor and epixylic species) and polypore fungi have also been commonly collected, whereas vertebrates have been studied rarely because their home ranges usually exceed the study scale, i.e., the stand. Exceptions are small mammals (voles, shrews) sampled in MONTA, and birds sampled in DISTDYN where the design consists of multiple landscapes of about 200-300 ha, so bird counts potentially produce sufficiently large and diverse data for analysis. Data on living and dead trees have been commonly collected, and assessments of the economic profitability of felling methods have been conducted in several experiments. Social dimension (public attitude to forest management) has thus far been assessed in NaturKultur and DISTDYN (Table 1).

\section{Ecological findings in VRF and restoration experiments}

Below we present main findings from the experiments (Table 1) for different species groups. We distinguish short- and long-term effects of VRF, prescribed burning, manipulation of deadwood, and possible other factors that were found to be important. An at-glance summary of these results can be found in Table 2 .

\section{Understory vegetation}

\section{Short-term responses to retention}

Increasing harvesting intensity causes increasingly drastic alterations in the species composition of understory vegetation. In mesic Norway spruce stands, resistance is higher in herbs than in other species groups, and latesuccessional bryophytes are particularly sensitive to harvesting (Jalonen and Vanha-Majamaa 2001; Götmark et al. 2005). Selection felling and gap felling change understory vegetation less than conventional clear felling or $7 \%$ retention felling (Jalonen and Vanha-Majamaa 2001). Uniform shelterwood felling accompanied by site preparation in Estonian Scots pine forests increased the species richness of vascular plants and bryophytes, largely through an increase in the number of pioneer species (Tullus et al. 2019).

\section{Long-term responses to retention}

The standard retention does not maintain species that require late-successional forest conditions, as even several times higher number of retention trees (about 50 trees per ha in a few groups) in spruce and pine forests does not support, e.g., mosses, liverworts, or lichens (Hämäläinen et al. 2016; Vanha-Majamaa et al. 2017). The general response to harvesting depends on the level of retention, possible other retention measures, and species in question (Bergstedt and Milberg 2001; Johnson et al. 2014; Vanha-Majamaa et al. 2017). Retention of 7\% (23 $\mathrm{m}^{3} \mathrm{ha}^{-1}$, in three groups) results in almost similar vegetation composition as clear felling in Norway spruce forests (Vanha-Majamaa et al. 2017). Corroborating results have been found in Scots pine-dominated stands for considerably higher retention $\left(50 \mathrm{~m}^{3} \mathrm{ha}^{-1}\right)$ (Johnson et al. 2014). Selection felling (67\% retained) and gap felling ( $50 \%$ retained) have rather similar long-term effects on understory vegetation, but resilience within these treatments is higher than in 7\% retention (Vanha-Majamaa et al. 2017). In Estonia, shelterwood felling had a small effect on bryophytes in Scots pine dominated stands but was destructive for bryophytes of conservation concern in mesic Norway spruce stands (Tullus et al. 2018). Moreover, in Scots pine forests, Rodriguez and Kouki (2015) showed that, 13 years after felling, blueberry (Vaccinium myrtillus) cover, flowering, and berry production were still lower than in unharvested forest, irrespective of retention level $\left(10\right.$ or $\left.50 \mathrm{~m}^{3} \mathrm{ha}^{-1}\right)$, whereas the resilience of lingonberry (Vaccinium vitisidaea) was higher (but see Granath et al. 2018). Riparian brook-side forests, studied in the PuroMONTA experiment in central Finland, are important for many rare and red-listed forest species (Selonen et al. 2011; Selonen and Kotiaho 2013; Selonen 2014; Oldén et al. 2019a). This experiment showed that if clear felling is applied in adjacent forests, unharvested buffer zones surrounding brooks must be at least $35-45 \mathrm{~m}$ wide to support the initial riparian plant and moss communities. Selection felling within these buffers affects indicator mosses negatively, apparently due to increasing light 


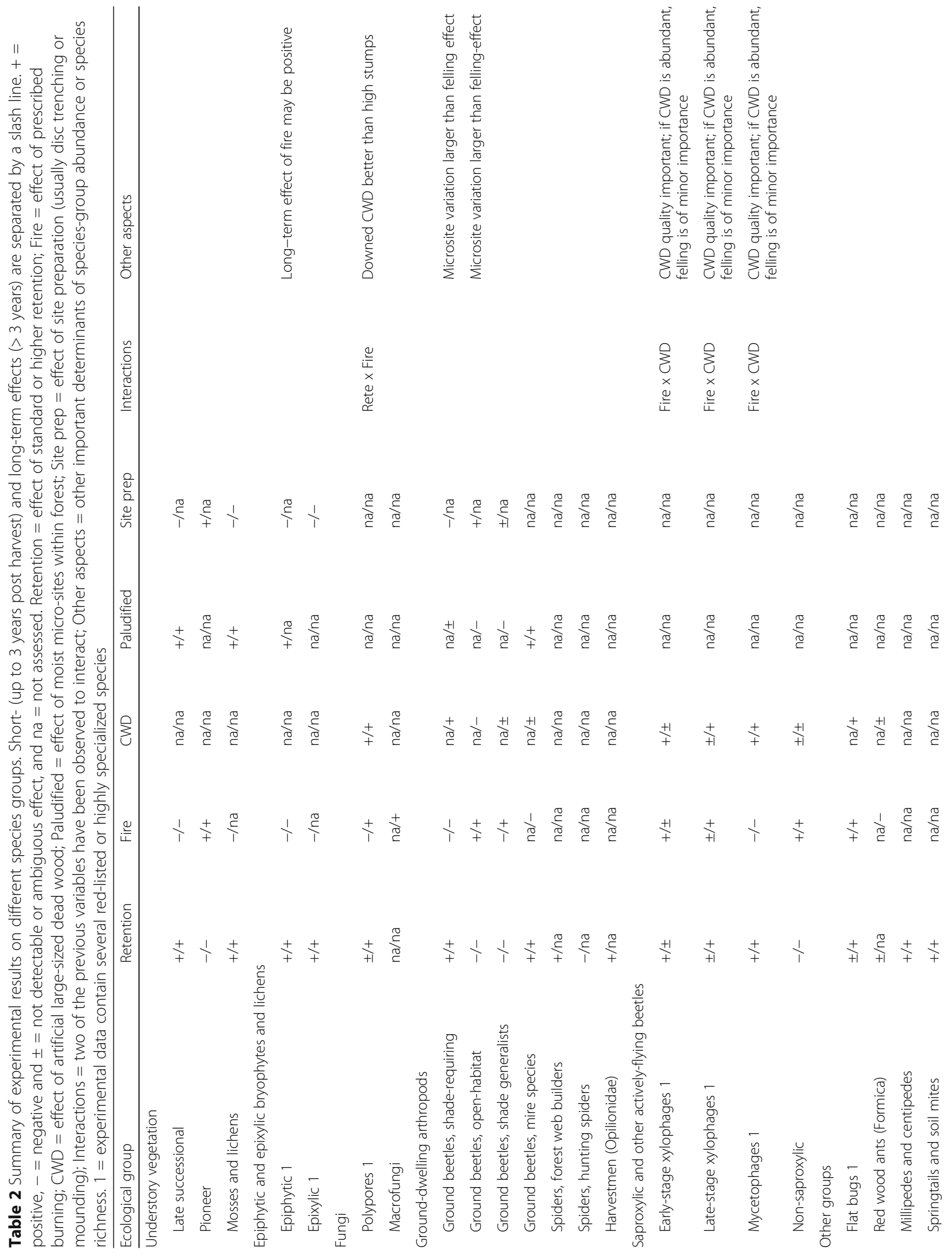




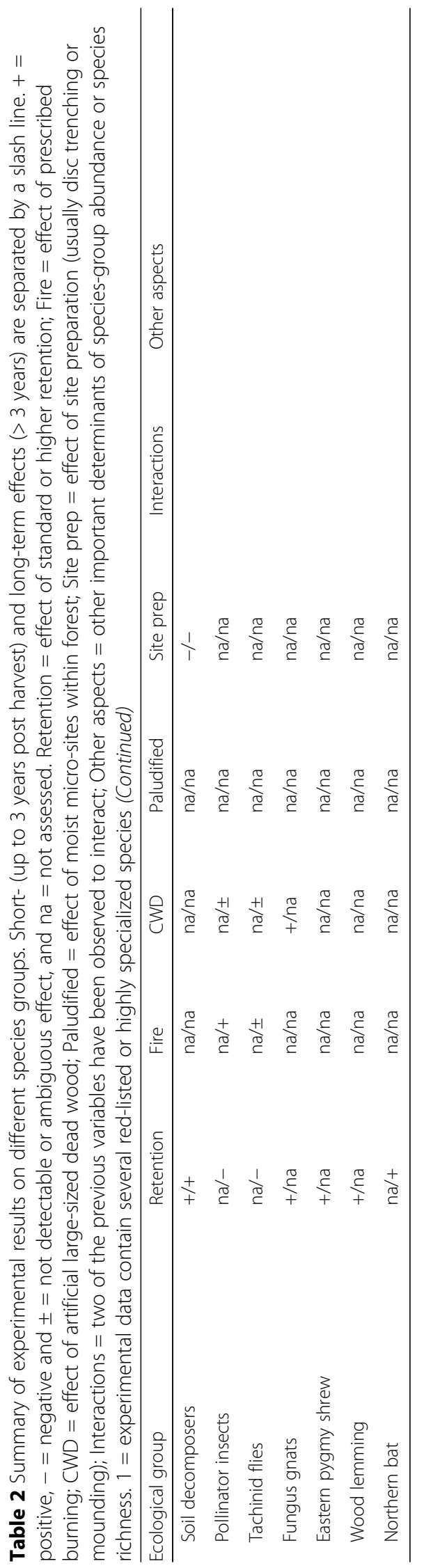


(canopy openness) and alterations in temperature and moisture (Oldén et al. 2019b).

\section{Prescribed burning}

Most short-term effects of burning, combined with VRF, on vegetation are negative even after a low-severity fire, but half of the understory species reappear within 23 years, and the number of early-successional species increases (Table 2, Vanha-Majamaa et al. 2007). Apart from time since fire, also forest type and climate zone are important predictors of the effects of burning on herbaceous plant richness (Eales et al. 2018). Burning combined with VRF may increase structural and microclimatic heterogeneity and promote preservation of biological legacies, such as CWD and remnant vegetation (Heikkala et al. 2014; Johnson et al. 2014). For instance, lingonberry benefits from increasing retention level at burned sites (Rodriguez and Kouki 2015; Granath et al. 2018).

\section{Manipulation of dead wood}

No results reported.

\section{Other aspects}

Site preparation at felled sites strongly impacts understory plants (Table 2). This impact generally takes place at within-stand level, thus impacting the spatial variation in abundance of plant species in the short term. The resilience of understory vegetation against site preparation is higher in gap-felled (about 0.16 ha gaps) than in 2 ha clear-felled stands with $7 \%$ aggregated retention, apparently due to microclimatic differences and edge effects (Vanha-Majamaa et al. 2017).

\section{Epiphytic and epixylic species}

\section{Short-term responses to retention}

Even if any retention supports some of the studied epixylic species (Table 2), higher than standard retention may not suffice for all of them. Perhans et al. (2009), Hautala (2008), and Hautala et al. (2011) studied retention patches of $0.01-0.60$ ha in different forest types in Sweden and Finland. These authors found that such patches were too small for some lichens and bryophytes, particularly liverworts, which suggest microclimatic changes and edge effects in the interiors of even the largest of these patches. Harvesting-caused change in the total number of epixylic species depends on retentionpatch size (Hautala et al. 2011), suggesting that larger patches maintain epixylic diversity better than smaller patches. Cover declines inside these patches are particularly striking for mosses, but the relative decrease may be highest for liverworts (Hautala et al. 2011). In Swedish temperate mixed oak forests, selection felling to release space for oak trees resulted in an increase in epixylic lichen but not in bryophyte richness (Paltto et al. 2008). These authors also found that red-listed species may be affected by selection felling only little, supporting Perhans et al. (2009) who found retention to mitigate declines of, or even increase, red-listed and indicator lichens.

\section{Long-term responses to retention}

Higher than standard retention, including group retention, may not suffice for all closed-canopy species. Hämäläinen et al. (2014) studied lichens in pine forests 11 years after felling and witnessed a negative effect of increasing felling intensity on micro-lichen richness. On the other hand, selection felling with $50 \%$ removal of trees did not markedly increase the mortality of aspen cyanolichens but it reduced their growth in northern Swedish spruce-dominated forests (Hedenås and Ericson 2003). In Swedish mixed oak forests, epixylic lichens and bryophytes benefited from selection felling aiming at releasing space for oak trees as compared to untreated reference forests (Nordén et al. 2012). Moreover, this operation also supported species of conservation concern, increased the colonization rate, and decreased the loss rate (Nordén et al. 2012). In Finnish spruce forests 10 years post-harvest, considerably more bryophyte species were lost after selection felling with $67 \%$ retention than after gap felling with $50 \%$ retention (Vanha-Majamaa et al. 2017). This finding suggests that aggregated retention supports bryophytes better than dispersed retention.

\section{Prescribed burning}

First-order effects of fire are negative to most epixylic and epiphytic species (Table 2). Effects of fire on these species can be short term (Rudolphi et al. 2011) but sometimes also long lasting. For example, epiphytic lichens in pine forests remained at lower level 11-12 years post fire (Hämäläinen et al. 2014; Hämäläinen 2016). Fire not only kills these species directly but also changes the quality of substrates and microclimatic conditions.

\section{Manipulation of dead wood}

No results reported.

\section{Other aspects}

Site preparation affects epixylic mosses and lichens negatively (Hautala et al. 2011; Rabinowitsch-Jokinen et al. 2012; see also Tullus et al. 2018, 2019). The effects of site preparation on substrates of these species (largesized CWD) depend on the site-preparation method and/or its intensity, but may cause up to $70 \%$ loss in the CWD volume (Hautala et al. 2011). Highly decayed CWD is particularly vulnerable to site preparation, which affects epixylic species richness and cover negatively (Hautala et al. 2011). Continuous site preparation methods, 
such as disc trenching, are more harmful for CWD (and thus epixylic species) than non-continuous methods, such as mounding (Rabinowitsch-Jokinen and Vanha-Majamaa 2010; Rabinowitsch-Jokinen et al. 2012).

\section{Fungi}

\section{Short-term effects of retention}

Polypores tend to decline in harvested areas, but the new substrates created in harvesting-stumps and logging residue-support some species (Table 2; Suominen et al. 2018, 2019). In VRF, tree deaths due to senescence, wind, or other factors may be expected to provide continuity of large-sized snags and logs that many polypores and other saproxylic species utilize (Junninen et al. 2008; Berglund et al. 2011). Even small numbers of retention trees, and stumps and logging residue (Berglund et al. 2011), are important for polypores (and for other saproxylic taxa; de Jong and Dahlberg 2017). Different groups of fungi respond in different ways: in southern Swedish mixed oak forests, selection felling to release space for oak trees benefited ascomycete fungi but caused declines of basidiomycete fungi (Nordén et al. 2008). Moreover, in Finnish brook-side forests, perennial, annual, or red-listed polypores did not show detectable short-term responses to selection felling inside $15-\mathrm{m}$ buffer zones between brook and clear cut (Timonen 2011).

\section{Long-term responses to retention}

High retention is more beneficial for pine-forest polypores than low retention (50 vs. $10 \mathrm{~m}^{3} \mathrm{ha}^{-1}$; Suominen et al. 2015, Table 2). Rare and red-listed polypores require long time to colonize substrate trees that die gradually due to wind impact, and indeed these species benefit from retention in the long term (Suominen 2018; Suominen et al. 2018, 2019); however, such effect was not detected by Pasanen et al. (2019).

\section{Prescribed burning}

The immediate effect of fire may be a general decline in species occurrences (Table 2), but most polypores and other macrofungi recover within a few years. Berglund et al. (2011) found no significant effects of different levels of downed-and-burned CWD on species composition or richness of polypores a few years after burning, but some species were positively affected. In the long term, many rare and red-listed polypores (Junninen et al. 2008; Suominen et al. 2018) and saprotrophic Basidiomycota and Ascomycota fungi (Salo et al. 2019) benefit from burning (Table 2). Higher retention at burned sites provides greater benefits at least in Scots pinedominated stands (Suominen et al. 2015), but the effect also depends on whether deadwood consists of stumps, slash, or whole trees (Suominen et al. 2019).

\section{Manipulation of dead wood}

High stumps and other intentionally killed trees support a wide spectrum of saproxylic species (Table 2; Olsson et al. 2011; Pasanen 2017), but compared to naturally died CWD, they host lower species richness (Pasanen et al. 2014, 2019) and their species compositions are different (Pasanen et al. 2018). Lindhe et al. (2004) showed, 9 years after CWD addition, that downed logs maintained higher species richness than high stumps, and that larger diameter of CWD had a positive effect on polypore richness.

\section{Other aspects}

No results reported.

\section{Ground-dwelling arthropods Short-term effects of retention}

Macro-arthropod (mostly spiders and beetles) richness and abundance increase after logging, but even standard retention mitigates some assemblage changes (Koivula 2002a; Pietikäinen et al. 2003; Table 2). Selection felling removing up to $25-30 \%$ of trees, or $30-50 \%$ of tree volume, does not affect these groups much (Koivula 2002b; Matveinen-Huju and Koivula 2008). Gap felling (50\% retention with three 0.16 -ha clearings per ha) retains the initial spider and ground beetle (Carabidae) faunas considerably better than standard retention, particularly in unharvested parts of these stands (Koivula 2002a; Koivula and Niemelä 2003; Matveinen-Huju et al. 2006, 2009; Martikainen et al. 2006a). Generally, following harvesting, species associated with closed canopies decline, whereas canopy generalists and open-habitat species increase rapidly (Niemelä et al. 2007). Aggregated retention (0.01-0.60 ha patches) also supports at least some of the ground beetle and spider species specialized on living under closed canopies and/or forest mires (Martikainen et al. 2006a; Matveinen-Huju and Koivula 2008). However, even in the largest of these patches, interior parts are apparently affected by adjacent clear-felled environments through various edge effects (MatveinenHuju et al. 2006, 2009; Matveinen-Huju 2007).

\section{Long-term effects of retention}

Ten years after logging, $0.01-0.03$ ha retention tree groups host lower densities of predatory spiders and open-habitat ground beetles than adjacent clear cuts, suggesting smaller assemblage change (Siira-Pietikäinen and Haimi 2009; Koivula et al. 2019; Table 2). Thus, even such small groups impact the spatial distribution and/or abundance of arthropods for a long time. Gap felling mitigates changes in the arthropod assemblages so that they may be little affected in unharvested fractions, whereas in gaps, alterations can be considerably larger and open-habitat species thrive (Koivula et al. 2019). 


\section{Prescribed burning}

Harvested and subsequently burned sites support higher ground beetle richness than either untreated or harvested-only sites in the short (Martikainen et al. 2006a) and in the long term (Toivanen et al. 2014) (Table 2). Interestingly, paludified patches within felled and burned sites host many mire specialist species, such as the ground beetle Platynus mannerheimii, at least 7 years after treatments (Toivanen et al. 2014). Similarly, in the short term, ground beetles tend to aggregate to retention patches of harvested-and-burned sites (Martikainen et al. 2006a). These studies exemplify the importance of structural heterogeneity of forests for the overall biodiversity and disturbance resistance.

\section{Manipulation of dead wood}

In the EVO experiment, 7 years after felling operations, higher down-wood retention affected ground beetle richness negatively, whereas closed-canopy species benefited, perhaps due to increasing shelter against direct sunlight or changes in other microclimatic factors (Toivanen et al. 2014) (Table 2).

\section{Other aspects}

Site preparation affects ground beetles so that closedcanopy specialists avoid, and open-habitat species prefer, strips of visible mineral soil in clearings (Table 2; Pihlaja et al. 2006). However, in a new analysis of data from Koivula (2002a), Koivula (2012) did not detect strong effects of site preparation. The impact on within-stand spatial distribution of individuals may nevertheless be larger than logging-caused effect (Koivula and Niemelä 2003). Similarly, Koivula (2001, 2002a) for the short and Toivanen et al. (2014) for the long term showed that moisture variation within stands may be a more important ground beetle assemblage determinant than felling or prescribed burning.

\section{Saproxylic and other actively flying beetles Short-term effects of retention}

The benefits of standard retention on saproxylic beetles are small (Heikkala et al. 2016a), but it supports some of these species, provided that CWD substrates are sufficiently abundant (Jokela et al. 2019) (Table 2). Saproxylic beetle abundance and richness increase rapidly after felling, but numbers return close to the background level within a few years in both pine and spruce forests (Hyvärinen et al. 2006; Toivanen 2007; Heikkala et al. 2016a, 2016b). These changes may be minor after selection felling (Joelsson et al. 2018a), but species composition may vary considerably within stands, as felling trails host different composition from the less open, selectively felled fractions (Joelsson et al. 2018b). Selection felling in spruce forests, aiming at an uneven age structure of trees, maintains the saproxylic beetle assemblage well, whereas ordinary commercial thinning causes large deviations (Hjältén et al. 2017a; Joelsson et al. 2017). In these operations, the amount of post-harvest CWD is important (Joelsson 2017). Gap felling, with gaps $20 \mathrm{~m}$ in diameter, benefits cambium consumers, particularly bark beetles (Scolytidae: Scolytinae), but has minor effects on the overall composition of the beetle assemblage (Hjältén et al. 2017b; Kärvemo et al. 2017). Specifically, xylophages of fresh CWD benefit from felling, apparently due to the rich pulse of slash and stumps, whereas some other species groups may decline, such as mycetophages (Heikkala et al. 2016b; Jokela et al. 2019; Table 2). If CWD is plentiful, retention level as such has often minor effects on saproxylic beetles unless there is no retention at all (Hyvärinen et al. 2005, 2009; Toivanen 2007; Toivanen and Kotiaho 2010; Heikkala et al. 2016b; Table 2). On the other hand, increasing size of felled gaps impacts non-saproxylic spruce-forest beetles positively (Jokela et al. 2019). Finally, in southern Swedish mixedoak forests, selection felling to release space for oak trees increased the richness of herbivorous and saproxylic beetles by about 35\% (Franc and Götmark 2008).

\section{Long-term responses to retention}

Heikkala et al. (2016a) showed that the overall species richness of saproxylic pine-forest beetles peaks within a few years from felling and then declines rapidly to the pre-treatment level, but late-stage xylophages remain abundant for at least 10 years (Table 2). Retention level per se has minor effects on saproxylic beetles (Toivanen and Kotiaho 2007a; Heikkala et al. 2016a). High level of retention, however, may protect pine saplings from pine weevil (Hylobius spp.) attacks, perhaps through providing alternative food sources for these beetles (Pitkänen et al. $2005,2008)$. Selection felling aimed at releasing space for oak trees in southern Swedish mixed forests continues to support saproxylic beetles for at least 10 years postharvest, whereas herbivorous beetles may not show a response any longer (Gran and Götmark 2019).

\section{Prescribed burning}

Fire rapidly changes the species composition (Hyvärinen 2006; Heikkala 2016; Hägglund and Hjältén 2018) and functional diversity of saproxylic beetles (Heikkala et al. 2016b), and increases their species richness, especially if combined with retention (Toivanen and Kotiaho 2007a; Hültén et al. 2017b; Table 2). These effects may remain detectable for at least 10 years (Heikkala et al. 2016a). Fire also supports open-habitat associated species (Heikkala et al. 2016b) and many red-listed and rare saproxylic species (Hyvärinen et al. 2006; Toivanen and Kotiaho 2007b), an effect that may become more pronounced with increasing amount of deadwood (Komonen et al. 2014). 
On the other hand, burning affects some bark beetles negatively (Toivanen and Kotiaho 2010), so prescribed burning may also decrease risks for economic damage (though see, e.g., Kärvemo et al. 2017).

\section{Manipulation of dead wood}

Artificial addition of CWD in harvesting operations (high stumps, girdled trees, pushed-down logs, etc.) positively affects cambium consumers and wood borers, including rare and red-listed species (Toivanen 2007; Toivanen and Kotiaho 2010; Table 2). The functioning of such CWD, however, depends on how trees are killed, and tree species (Hägglund and Hjältén 2018). Such operations might be thought to increase risks of bark beetle outbreaks, but sampling at pine and spruce retention-felling sites suggests that these risks are small (Martikainen et al. 2006b; Toivanen et al. 2009). Felled and standing pieces of artificial CWD host partly different beetle assemblages so that cambium consumers, fungivores and red-listed species may be more common in the latter (Gibb et al. 2006; Johansson et al. 2006; Hjältén et al. 2010; Andersson et al. 2015). Furthermore, high stumps of different decay stages and tree species host different beetle assemblages (Lindhe and Lindelöw 2004). Moreover, in a Norwegian high-stump experiment, high stumps at clear-cut edges hosted different beetle assemblages from high stumps located at central parts of clear cuts (Fossestol and Sverdrup-Thygeson 2009), probably because of microclimatic factors, sun exposure and edge effects.

\section{Other aspects}

The species of a dying or dead retention tree appears important for saproxylic species in general, as each tree species hosts a distinctive set of specialists (Toivanen 2007; Toivanen and Kotiaho 2010).

\section{Other taxa}

\section{Short-term effects of retention}

Johansson et al. (2010) and Hägglund et al. (2015) detected an overall increase of flat bugs (Heteroptera: Aradidae) following gap harvesting in Swedish spruce forests. Heikkala et al. (2017) found that retention in pine-forest clear cuts supports these species (Table 2). Also the decomposer community is impacted by felling method. Siira-Pietikäinen et al. (2001) and Siira-Pietikäinen (2002) found that the community structure, as indicated by phospholipid fattyacid pattern, changed in the first year, followed by declines in microbial biomass and respiration in the second, and an increase of Enchytraeidae worms in the third year in clear cuts. However, selection felling had no detectable impact on the decomposer community. In the MONTA experiment, short-term effects of felling on common small mammals broadly followed species habitat requirements. Thus, the field vole (Microtus agrestis) benefited, whereas the bank vole (Myodes glareolus) suffered, from felling; interestingly, the Eurasian pygmy shrew (Sorex minutus) seemed to benefit from small retention patches left in clear cuts (Heikki Henttonen, pers. comm.). The latter seems to benefit from forest edge habitats (Henttonen et al. 1998). The wood lemming (Myopus schisticolor), a specialist of old mossy spruce forests, was scarce in most years. In the first post-harvest summer, however, it was remarkably abundant in reference stands but remained scarce in up to 0.03-ha retention patches of clear-felled stands (Heikki Henttonen, pers. comm.).

\section{Long-term responses of retention}

Siira-Pietikäinen and Haimi (2009) showed in Norway spruce forests that enchytraeid worms remain at elevated levels in clear cuts and gap felled stands for at least 10 years. In the same study, macro-arthropods declined in these two treatments but not in selection felling, particularly herbivores, microbivores, and some detritivores. The decomposer community remained affected for the entire 10-year follow-up, and up to 0.03-ha retention tree groups appeared similar to the surrounding clearfelled parts of the same stands (Siira-Pietikäinen and Haimi 2009; Table 2). In pine forests of the FIRE experiment, felling impacted the pollinator community strongly, whereas the retention level $\left(10\right.$ or $\left.50 \mathrm{~m}^{3} \mathrm{ha}^{-1}\right)$ had only a minor effect (Rodriguez and Kouki 2017; Table 2). Bees (Apidae) and hoverflies (Syrphidae) in particular were more abundant in felled than in unharvested forests; the latter hosted a subset of the assemblage found in felled sites. The general felling-caused increase was associated with the amount of deadwood (perhaps reflecting structural heterogeneity and consequent nesting sites), blueberry and lingonberry flower abundance (foraging), and exposed mineral soil (important particularly for solitary bees) (Rodriguez and Kouki 2015). Moreover, tachinid flies (Diptera: Tachinidae) that parasitize herbivorous insects had higher richness due to felling, which was associated with the functional diversity of plants (Rodriguez Olmo 2018). Retention trees as such are important too: Thorn et al. (2018) found, 15 years after felling, that Northern bats (Eptesicus nilssonii) roost under the loose bark of standing dead trees in clear-felled pine forests.

\section{Prescribed burning}

In the short term, flat bugs benefit from burning, indicated by the elevated richness and abundance of rare and red-listed species (Johansson et al. 2010; Hägglund et al. 2015; Hägglund 2016; Heikkala et al. 2017; Table 2). However, retention level in burned pine stands (10 or $50 \mathrm{~m}^{3} \mathrm{ha}^{-1}$ ) was not important for flat bugs (Heikkala et al. 2017). Mound-building ants (Formica rufa group, red wood ants), on the other hand, were negatively 
affected by burning and decreasing level of retention in the EVO experiment, whereby lower retention had apparently contributed to a more intense soil-surface fire, thus damaging ant mounds (Toivanen et al. 2014; Table 2). In the long term, pollinator insects benefit from fire, possibly through fire-caused increase in structural heterogeneity (Rodriguez and Kouki 2015, 2017). Moreover, in an exclosure experiment, den Herder et al. (2009) showed that burning decreased the browsingcaused mortality of deciduous trees, possibly because burned forests are relatively open, providing little shelter for moose, deer, and hare.

\section{Manipulation of dead wood}

No results reported.

\section{Other aspects}

Økland et al. (2008) found, in mixed oak forests in southern Sweden, that logging residue from selection felling of other than oak trees supported woodassociated fungus gnats (Mycetophilidae).

\section{Wrap-up of biodiversity responses to VRF and restoration}

The studied experiments, reviewed above, demonstrated that responses to felling and restoration operations vary greatly, depending on species or taxonomic group, and that many if not most effects are detectable for more than 10 years. From management and conservation points of view, however, not all responses are equally (or ecologically) important. This is because most species thrive in present-day managed forests, whereas redlisted and other highly specialized species do not, so the latter should determine management and conservation actions. Below, we do not discuss the above findings species group by species group, but at a general level: shortand long-term responses of forest biodiversity to VRF, prescribed burning, manipulation of dead wood, and other findings. We end this paper with suggestions to modify forest management and point out knowledge gaps for future research.

\section{Short-term responses of forest biodiversity to VRF}

Many species respond positively to felling operations, apparently due to released resources (light, minerals, competition-free sites) and certain ephemeral resources, particularly fresh CWD (residue and stumps); moreover, many rare or red-listed species benefit from the latter. The standard retention, ten trees per ha, is insufficient to maintain biodiversity at the stand level, as even several times higher amount of retention does not mitigate the effects of harvesting particularly on specialist species (Perhans et al. 2009; Hautala et al. 2011; Johnson et al. 2014; Vanha-Majamaa et al. 2017). In Fennoscandia, the prevailing retention method is aggregated retention. Retention patches should be preferably at least 1 ha in size, as retention patches of up to $0.6 \mathrm{ha}$, or nearly $50-\mathrm{m}$ wide riparian buffer zones against clear cuts, were shown to be too small to maintain the initial core-habitat species composition, largely due to microclimatic changes associated with edge effects (Chen et al. 1993; Heliölä et al. 2001; Oldén et al. 2019b). These findings are in accordance with North American research (e.g., Nelson and Halpern 2005).

Another important aspect in VRF is tree-species composition. In practical management, the decision on which tree species to retain is often based on susceptibility to wind or other mortality factors, and timber value: retention trees are often aspen or other low-economic value species. Hämäläinen et al. (2016) found in harvested Scots pine-dominated forests that smaller, aggregates of, and pine or birch, trees were less prone to mortality than larger, dispersed, and spruce, respectively. Decisions concerning retention patch size and composition are also ecologically important: epiphytic lichens growing on deciduous trees may benefit, whereas lichens growing on spruce may decline, following felling (Ranlund et al. 2018). Spruce forests are generally shadier than other forests, and lichens are adapted accordingly, thus being more sensitive to changes in light conditions (Esseen and Renhorn 1998; Rheault et al. 2003).

\section{Long-term responses of forest biodiversity to VRF}

Community compositions of most groups of forest species reflect felling treatments for at least 10 years. However, any retention mitigates some community changes, and with about 50\% dispersed retention, most shadeassociated species thrive in managed stands. In other words, community alterations become more pronounced the more intense the felling method. Also, the long-term resilience after felling varies among taxonomic groups. Among understory plants, herbs are rather resilient, whereas mosses, liverworts, and dwarf shrubs require tens of years to recover (Reinikainen et al. 2000; Hedwall et al. 2013; Tonteri et al. 2016; Vanha-Majamaa et al. 2017). Timber harvesting generally has minor effects on frequent ectomycorrhizal fungi in a 30-50 years perspective (Varenius et al. 2016), whereas polypores in forests that had been selectively felled hundred years earlier still reflected an initial 10-80\% felling-intensity gradient (Bader et al. 1995). This finding suggests that the overall biodiversity does not fully recover until the structures and microclimate return to near-pristine conditions. The size, species, and quality of retained trees are important in this respect (Kuuluvainen et al. 2019).

Retention reduces negative long-term biodiversity impacts. We show above that increasing retention supports red-listed polypores, a finding similar to a 
Northern Finnish chronosequence of selectively felled forests (Sippola et al. 2004). Even single retained aspen trees support some epiphytic bryophytes and lichens (Hazell and Gustafsson 1999) and rare and redlisted beetles (Martikainen 2000). Sometimes conservation requires thinking the other way around: examples include selective felling to release space for oak trees in southern Swedish mixed forests (see above), and intermediateintensity felling that supported the lichen Usnea longissima in Norway (Storaunet et al. 2008, 2014) and some old-growth lichen species in Estonia (Lõhmus et al. 2012).

As we show above, aggregated retention may be better than dispersed retention at least for bryophytes. Similarly, the diversity of epiphytic and epixylic indicator lichens was maintained better in retention patches than on solitary trees in Northern Finnish spruce forests (Ylisirniö and Hallikainen 2018). The relative benefits of dispersed and aggregated retention in North European conditions would clearly warrant more research (e.g., Lencinas et al. 2008; Lee et al. 2017).

\section{Short- and long-term impacts of prescribed burning}

Short-term effects of prescribed burning are negative on most species groups, except for pyrophilous species. In the long term, burning benefits open-habitat associated and saproxylic species, including red-listed ones. Epiphytic lichens show negative long-term responses 10 15 years post fire (Table 2), but an Estonian study suggests that the trend may turn positive a few years later (Lõhmus et al. 2018). Accordingly, prescribed burning combined with retention higher than $50 \mathrm{~m}^{3} \mathrm{ha}^{-1}$ may have positive long-term effects on the species composition, occurrence, and abundance of rare and threatened polypores (Penttilä and Kotiranta 1996; Penttilä et al. 2013).

As we show above, understory plants, polypores, and ground-dwelling arthropods face smaller changes the higher the retention at burned sites. Retention at fire sites improves conditions for saproxylic species, but it also supports pyrophilous species (Wikars 1995) and common shade-associated species (see above). Openhabitat associated species, on the other hand, do better the lower the retention at fire sites (see above); similarly, a Norwegian study at a post-fire stand reported high abundance of open-habitat associated ground beetles, such as Pterostichus adstrictus (Gongalsky et al. 2006).

Prescribed burning impacts also micro-sites and substrates for species. In spruce-dominated forests, burning may affect within-site moisture variability, as the watertable level rises following fire, thus potentially increasing topography-related paludification in depressions. On the other hand, fire may destroy up to $40 \%$ of the pretreatment CWD, particularly CWD of advanced decay (Eriksson et al. 2013), and thereby only partly contribute to the CWD continuity. Moreover, fire increases the surface area of charred wood (>50\%) and reduces vegetation cover on these pieces of wood by $60-98 \%$ (Eriksson et al. 2013). The new CWD created by prescribed burning is also determined by the level of retention and stand age (Sidoroff et al. 2007).

\section{Artificial deadwood and retention trees benefit saproxylic species, but with preconditions}

The amount and quality of CWD are important richness determinants of saproxylic species (e.g., Similä et al. 2003; Santaniello 2017; Santaniello et al. 2017a; Jokela et al. 2018). Artificial CWD, mostly as high stumps, supports saproxylic organisms; however, these CWD also host partly different communities from CWD of natural origin. The quality of artificial CWD is important for many threatened specialists. Felled or standing pieces of artificial CWD host partly different beetle assemblages so that cambium consumers, fungivores, and red-listed species may be more common in standing CWD (Sverdrup-Thygeson and Ims 2002; Lindhe et al. 2004; Gibb et al. 2006; Hjältén et al. 2010; Andersson et al. 2015). Furthermore, high stumps of different decay stages and tree species host different beetle assemblages (Lindhe and Lindelöw 2004; Lindbladh et al. 2007; Jonsell and Hansson 2011; Stokland et al. 2012; Jonsell et al. 2019; Sandström et al. 2019), indicating biodiversity benefits of a continuous supply of CWD. Moreover, decomposer fungi determine the beetle assemblage in high stumps (Jonsell et al. 2005; Abrahamsson et al. 2008). Hence diversities of different taxonomic groups seem to be tied together, and an impact to one group may have cascading effects on the whole ecosystem.

Increasing retention results in higher amount and more diverse quality of CWD (Santaniello et al. 2016, 2017b), and retention tree groups also add structural variation to managed forests (Kruys et al. 2013). The location (site type) and size (level of retention) of retention tree groups are important determinants of the muchneeded continuity of large-sized CWD for saproxylic species. In spruce forests, retention tree groups should preferably be placed in paludified patches with initially more CWD of different stages of decay as compared to upland patches (e.g., 16 vs. $2 \mathrm{~m}^{3} \mathrm{ha}^{-1}$; Vanha-Majamaa and Jalonen 2001) to "lifeboat" species over the regeneration phase. This way, much if not most of the initial CWD might be retained (Hautala et al. 2004). Another motive is to mimic natural disturbances, as in natural conditions these sites burn less often than upland sites (Wallenius et al. 2004). However, susceptibility to uprooting is higher in paludified than in upland sites: during the first few post-harvest years in spruce forests, uprooting percentages in these biotopes were 48 and 15, respectively (Hautala and Vanha-Majamaa 2006; Hautala 
et al. 2011). Moreover, Heikkala et al. (2014) found that retention of $10 \mathrm{~m}^{3} \mathrm{ha}^{-1}$ apparently did not contribute much to the continuity of CWD as trees died rather quickly, whereas in $50 \mathrm{~m}^{3} \mathrm{ha}^{-1}$ trees died over a longer time and thus functioned considerably better in this respect. Site type and retention level thus largely determine the future formation of CWD: formation can be faster in paludified than in upland sites, whereas the continuity may be better in the latter and with increasing retention level.

\section{The ecological importance of paludified patches, site preparation and logging residue}

Paludified patches in spruce forests, particularly if left unharvested, are important for the population maintenance of many forest-species groups, such as epixylic and epiphytic vegetation and beetles occupying spruce mires. Earlier research suggests that these patches are crucial for some red-listed specialists, such as the beetle Pytho kolwensis (Siitonen and Saaristo 2000). In the Russian part of Fennoscandia, paludified patches have been retained for almost a hundred years (Shorohova et al. 2019). Regrettably, research on biodiversity effects of this practice is largely missing but even ad hoc sampling at these sites would provide insights into long-term effects of VRF.

According to the Finnish Forest Act, paludified patches and certain other woodland key biotopes may be managed cautiously with selection felling (www.finlex.fi). It is notable, however, that in most of the abovereviewed experiments, and in available data about their stand characteristics, these patches had often not been identified and located. Such lack of information may lead to unintentional felling of these sites; most harvesting is done in winter months, when the snow cover makes their identification challenging. Due to the ecological importance of paludified patches, it would be important to describe, map, and completely retain them when implementing harvesting operations.

It is notable that even though site preparation has been widely used since the 1960 s, its effects have earlier seldom been separated from the effects of felling per se. Site preparation shapes the within-site spatial distribution of understory plants and beetles. Combined with felling, however, it also partly determines the retention and continuity of CWD at harvested sites (Haeussler et al. 2004). With dispersed retention, the disturbance on CWD may concern the whole harvesting area, whereas aggregated retention may preserve CWD at least in retained fractions. In clear cuts, nearly $10 \%$ of the pre-treatment volume of CWD is destroyed by harvesting machinery, and subsequent disc trenching may destroy an additional 70\% (Hautala et al. 2004). Disc trenching may have destroyed 4-6 $\mathrm{M} \mathrm{m}^{3}$ of CWD during 1960-2000 in Finland alone (Hautala et al. 2004), which has probably greatly contributed to the loss of saproxylic organisms, such as epixylic species (Rabinowitsch-Jokinen et al. 2012). This method was the most common site preparation method in Finland until 2005, after which mounding has become more common (Anonymous 2014). However, even mounding may destroy over 30\% of CWD, including 70\% of CWD of advanced decay, especially if combined with stump harvesting (Rabinowitsch-Jokinen and Vanha-Majamaa 2010). These findings indicate that site preparation is particularly devastating for specialists of advanced-decay CWD-and may well locally break down the continuity of such deadwood. Hence CWD quality, not just amount, should be considered in assessments of forest management.

We show also that logging residue and stumps are useful resources for saproxylic species, particularly beetles (Jonsell and Schroeder 2014). However, residue and stumps are often targeted by energy-wood harvesting (Ranius et al. 2018). This practice impacts saproxylic beetles negatively through a loss of substrates (Victorsson and Jonsell 2014; Work et al. 2016; Ranlund and Victorsson 2018) and through functioning as ecological traps: piles of residue and stumps-with beetles in them-are eventually moved from forest to power plants (Hedin et al. 2008; Victorsson and Jonsell 2013). A modeling study suggests that the risk of extinction of these species may be small if only $10 \%$ of the total clear-cut area in a forested landscape is stump harvested, but the risk rises with increasing intensity of extraction (Persson and Egnell 2018). Harvesting of stumps and residuals also impacts, e.g., epiphytic and epixylic species through exposing mineral soil and destroying CWD; lichens are more severely impacted by slash removal than by stump removal (Hiron et al. 2017).

\section{Future research needs}

In many of the reviewed papers, results have been reported by species groups, which may produce estimations too general for conservation or management purposes about the effects of felling, burning or high stumps. Almost all such groups include species with positive, neutral, and negative responses to these factors. Most of the reviewed species (groups) thrive in managed forests, whereas a small fraction (specialized and redlisted species) does not. Considering the low percentage of Fennoscandian forests dominated by natural disturbances, processes, and structural features, conservation and management efforts should focus on supporting this fraction. Indeed, the member nations of the European Union (EU) have accepted the EU Biodiversity Strategy, which "aims to halt the loss of biodiversity and ecosystem services in the EU and help stop global biodiversity loss by 2020" (Anonymous 2019b). 
Landscape structure may determine benefits of VRF, restoration, and other conservation measures (Hanski 2000; Hedenås and Ericson 2008), so that areas with generally more resources (habitat, substrates, etc.) would be better in this respect. Kouki et al. (2012) have shown that these benefits may also partly depend on regional land-use history. However, in a series of Swedish studies, nearby areas of high conservation value did not determine saproxylic beetle diversity of high stumps, whereas the timber volume and tree-species composition of surrounding forests did (Lindbladh and Abrahamsson 2008; Abrahamsson et al. 2009; Hallinger et al. 2018; Jonsell et al. 2019).

Forest practitioners are under increasing pressure to better account for a diverse set of values, including biodiversity, in management operations. This cannot be achieved without a solid basis on research. We identify the following knowledge gaps: (i) merits of aggregated and dispersed retention, and threshold sizes of felled gaps; (ii) modifications of site preparation, and their ecological effects; (iii) mechanisms behind species responses to forest management; (iv) impacts of forest management on inter-specific relationships; (v) species resilience and community-level responses at the landscape level; (vi) effects of VRF on ecosystem functioning and ecosystem services (carbon dynamics, nutrient cycling etc.); and (vii) meta-analysis of the effects of VRF and prescribed burning.

\section{Conclusions}

Retention levels may not reach, let alone exceed, 50\% in the foreseeable future in countries whose economy largely relies on forest industry, such as Finland, Sweden, and Russia. However, some actions to support biodiversity do not increase harvesting costs considerably. These include retention of existing CWD, damaged trees, and tree species of minor economic value. Felling operations can be planned and implemented so as to maintain the CWD continuum and, in turn, saproxylic species. The success, however, depends on updating forester education and public awareness about the importance of biodiversity, ecosystem services, and aesthetic, recreational and other multiple-use values. As shown in our review, the amount and quality of legacies are more important than the VRF method per se for many red-listed species. By maintaining or even artificially increasing CWD and some large-sized trees in harvested sites, many if not most saproxylic species can be life-boated over the regeneration phase.

\section{Supplementary information}

Supplementary information accompanies this paper at https://doi.org/10. 1186/s13717-019-0209-1.

Additional file 1: Table S1. Papers from Fennoscandian retention and restoration experiments, sorted according to experiment acronym (compare Table 1) followed by first author and publication year.
Abbreviations

CWD: Coarse woody debris; VRF: Variable retention forestry

\section{Acknowledgments}

We would like to thank two anonymous reviewers and Henrik Lindberg for constructive comments that improved the content substantially.

Authors' contributions

Both authors collaborated in equal participation to write the manuscript. Both authors read and approved the final manuscript.

Authors' information

No additional information.

Funding

Different projects from national and international calls between 1995 and present.

\section{Availability of data and materials}

Not applicable.

Ethics approval and consent to participate

No ethical issues or conflicts of interest exist.

Consent for publication

The authors consent to publish the data included in this draft.

\section{Competing interests}

The authors declare that they have no competing interests.

\section{Author details}

${ }^{1}$ School of Forest Sciences, University of Eastern Finland, P.O. Box 111, Fl-80101 Joensuu, Finland. ${ }^{2}$ Natural Resources Institute Finland (Luke), Latokartanonkaari 9, Fl-00790 Helsinki, Finland.

Received: 16 October 2019 Accepted: 13 December 2019

Published online: 06 February 2020

\section{References}

Abrahamsson M, Jonsell M, Niklasson M, Lindbladh M (2009) Saproxylic beetle assemblages in artificially created high-stumps of spruce (Picea abies) and birch (Betula pendula/pubescens) - does the surrounding landscape matter? Insect Conserv Div 2:284-294

Abrahamsson M, Lindbladh M, Rönnberg J (2008) Influence of butt rot on beetle diversity in artificially created high-stumps of Norway spruce. For Ecol Manag 255:3396-3403

Äijälä O, Koistinen A, Sved J, Vanhatalo K, Väisänen P (eds) (2019) Metsänhoidon suositukset. Tapion julkaisuja. $252 \mathrm{p}$ (in Finnish)

Andersson J, Hjältén J, Dynesius M (2015) Wood-inhabiting beetles in low stumps, high stumps and logs on boreal clear-cuts: implications for dead wood management. PLoS One 10:e0118896

Anonymous (2014) Finnish statistical yearbook of forestry 2014. Finnish Forest Research Institute, Vantaa

Anonymous (2016) Forest resources. Natural Resources Institute Finland (Luke) www.luke.fi/en/natural-resources/forest/forest-resources-and-forest-planning/ forest-resources (Accessed 11 July 2019)

Anonymous (2019a) Best practices for sustainable forest management. Tapio Ltd. www.metsanhoitosuositukset.fi/briefly-in-english (Accessed 10 July 2019)

Anonymous (2019b) Biodiversity strategy in a nutshell. European Commission. ec.europa.eu/environment/nature/biodiversity/strategy/ index_en.htm (Accessed 10 Aug 2019)

ArtDatabanken (2015) Rödlistade arter i Sverige. Artdatabanken, SLU. 211 pp (in Swedish)

Bader P, Jansson S, Jonsson BG (1995) Wood-inhabiting fungi and substratum decline in selectively logged boreal spruce forests. Biol Conserv 72:355-362

Beese WJ, Deal J, Dunsworth BG, Mitchell SJ, Philpot T (2019) Two decades of variable retention in British Columbia: a review of its implementation and effectiveness for biodiversity conservation. Ecol Process 8:33

Berglund H, Jönsson MT, Penttilä R, Vanha-Majamaa I (2011) The effects of burning and dead-wood creation on the diversity of pioneer wood-inhabiting fungi in managed boreal spruce forests. For Ecol Manag 261:1293-1305 
Bergstedt J, Milberg P (2001) The impact of logging intensity on field-layer vegetation in Swedish boreal forests. For Ecol Manag 154:105-115

Chen J, Franklin JF, Spies TA (1993) Contrasting microclimates among clearcut, edge, and interior of old-growth Douglas-fir forest. Agric Forest Meteorol 63:219-237

de Jong J, Dahlberg A (2017) Impact on species of conservation interest of forest harvesting for bioenergy purposes. For Ecol Manag 383:37-48

den Herder M, Kouki J, Ruusila V (2009) The effects of timber harvest, forest fire, and herbivores on regeneration of deciduous trees in boreal pine-dominated forests. Can J For Res 39:712-722

Djupström L, Weslien J (2019) Effaråsen - att bruka och bevara i gammal tallskog. SkogForsk Arbetsrapport:1009-2019 31 pp (in Swedish)

Drössler L (2016) Heterogen skog - för komplex för skogsbruk och tillämpad skogsforskning? Rön för Sveriges Lantbruksuniversitet Nr 9. 4 pp (in Swedish)

Eales J, Haddaway NR, Bernes C, Cooke SJ, Jonsson BG, Kouki J, Petrokofsky G, Taylor JJ (2018) What is the effect of prescribed burning in temperate and boreal forest on biodiversity, beyond pyrophilous and saproxylic species? A systematic review. Environ Evid 7:19

Eriksson AM, Olsson J, Jonsson BG, Toivanen S, Edman M (2013) Effects of restoration fire on dead wood heterogeneity and availability in three Pinus sylvestris forests in Sweden. Silva Fenn 47:954.

Esseen P, Renhorn K (1998) Edge effects on an epiphytic lichen in fragmented forests. Conserv Biol 12:1307-1317

Esseen PA, Ehnström B, Ericson L, Sjöberg K (1997) Boreal forests. Ecol Bull 46:16-47

Fedrowitz K, Koricheva J, Baker SC, Lindenmayer DB, Palik B, Rosenvald R, Beese W, Franklin JF, Kouki J, Macdonald E, Messier C, Sverdrup-Thygeson A, Gustafsson L (2014) Can retention forestry help conserve biodiversity? A meta-analysis. J Appl Ecol 51:1669-1679

Fossestol KO, Sverdrup-Thygeson A (2009) Saproxylic beetles in high stumps and residual downed wood on clear-cuts and in forest edges. Scand J For Res 24: 403-416

Franc N, Götmark F (2008) Openness in management: hands-off vs partial cutting in conservation forests, and the response of beetles. Biol Consenv 141:2310-2321

Gibb H, Pettersson RB, Hjältén J, Hilszczanski J, Ball JP, Johansson T, Atlegrim O, Danell K (2006) Conservation-oriented forestry and early successional saproxylic beetles: responses of functional groups to manipulated dead wood substrates. Biol Conserv 129:437-450

Gongalsky KB, Midtgaard F, Overgaard HJ (2006) Effects of prescribed forest burning on carabid beetles (Coleoptera: Carabidae): a case study in SouthEastern Norway. Entomol Fenn 17:325-333

Götmark F, Paltto H, Nordén B, Götmark E (2005) Evaluating partial cutting in broadleaved temperate forest under strong experimental control: short-term effects on herbaceous plants. For Ecol Manag 214:124-141

Gran O, Götmark F (2019) Long-term experimental management in Swedish mixed oak-rich forests has a positive effect on saproxylic beetles after 10 years. Biodivers Conserv 28:1451-1472

Granath G, Kouki J, Johnson S, Heikkala O, Rodríguez A, Strengbom J (2018) Trade-offs in berry production and biodiversity under prescribed burning and retention regimes in boreal forests. J Appl Ecol 55:1658-1667

Gustafsson L, Hannerz M, Koivula M, Shorohova E, Vanha-Majamaa I, Weslien J (2020) Research on retention forestry in northern Europe. Ecol Process. https://doi.org/10.1186/s13717-019-0208-2

Gustafsson L, Kouki J, Sverdrup-Thygeson A (2010) Tree retention as a conservation measure in clear-cut forests of northern Europe: a review of ecological consequences. Scand J For Res 25:295-308

Haeussler S, Bartemucci P, Bedford L (2004) Succession and resilience in boreal mixedwood plant communities $15-16$ years after silvicultural site preparation. For Ecol Manag 199:349-370

Hägglund R (2016) Ecological restoration of natural disturbances in boreal forests. Doctoral thesis, Sveriges Lantbruksuniversitet, Umeå, p 52

Hägglund R, Hekkala A-M, Hjältén J, Tolvanen A (2015) Positive effects of ecological restoration on rare and threatened flat bugs (Heteroptera: Aradidae). J Insect Conserv 19:1089-1099

Hägglund R, Hjältén J (2018) Substrate specific restoration promotes saproxylic beetle diversity in boreal forest set-asides. For Ecol Manag 425:45-58

Hagner M (1992) Biologiskt och ekonomiskt resultat i fältförsök med plockhuggning kombinerad med plantering. Arbetsrapport 63, Sveriges Lantbruksuniversitet, Umeå (in Swedish)

Hallinger M, Karvemo S, Ranius T (2018) Does it pay to concentrate conservation efforts for dead-wood dependent insects close to existing reserves: a test on conservation planning in Sweden. Insect Conserv Div 11:317-329
Hämäläinen A (2016) Retention forestry and intensified biomass harvest: epiphytic lichen assemblages under opposing ecological effects in pinedominated boreal forests. Doctoral thesis, University of Eastern Finland, Joensuu, p 33

Hämäläinen A, Hujo M, Heikkala O, Junninen K, Kouki J (2016) Retention tree characteristics have major influence on the post-harvest tree mortality and availability of coarse woody debris in clear-cut areas. For Ecol Manag 369:66-73

Hämäläinen A, Kouki J, Lõhmus P (2014) The value of retained scots pines and their dead wood legacies for lichen diversity in clear-cut forests: the effects of retention level and prescribed burning. For Ecol Manag 324:89-100

Hanski I (2000) Extinction debt and species credit in boreal forests: modelling the consequences of different approaches to biodiversity conservation. Ann Zool Fenn 37:271-280

Hautala H (2008) Disturbance in boreal spruce forest - immediate dynamics from stand to understorey level. Doctoral thesis, University of Helsinki, Helsinki, p 30

Hautala H, Jalonen J, Laaka-Lindberg S, Vanha-Majamaa I (2004) Impacts of retention felling on coarse woody debris (CWD) in mature boreal spruce forests in Finland. Biodivers Conserv 13:1541-1554

Hautala H, Laaka-Lindberg S, Vanha-Majamaa I (2011) Effects of retention felling on epixylic species in boreal spruce forests in southern Finland. Restor Ecol 19:418-429

Hautala H, Vanha-Majamaa I (2006) Immediate tree uprooting after retention-felling in a coniferous boreal forest in Fennoscandia. Can J For Res 36:3167-3172

Hazell P, Gustafsson L (1999) Retention of trees at final harvest—evaluation of a conservation technique using epiphytic bryophyte and lichen transplants. Biol Conserv 90:133-142

Hedenås H, Ericson L (2003) Response of epiphytic lichens on Populus tremula in a selective cutting experiment. Ecol Appl 13:1124-1134

Hedenås H, Ericson L (2008) Species occurrences at stand level cannot be understood without considering the landscape context: Cyanolichens on aspen in boreal Sweden. Biol Conserv 141:710-718

Hedin J, Isacsson G, Jonsell M, Komonen A (2008) Forest fuel piles as ecological traps for saproxylic beetles in oak. Scand J For Res 23:348-357

Hedwall P-O, Brunet J, Nordin A, Bergh J (2013) Changes in the abundance of keystone forest floor species in response to changes of forest structure. J Veg Sci 24:296-306

Heikkala O (2016) Emulation of natural disturbances and the maintenance of biodiversity in managed boreal forests: the effects of prescribed fire and retention forestry on insect assemblages. Doctoral thesis, University of Eastern Finland, Joensuu, p 46

Heikkala O, Martikainen P, Kouki J (2016a) Decadal effects of emulating natural disturbances in forest management on saproxylic beetle assemblages. Biol Conserv 194:39-47

Heikkala O, Martikainen P, Kouki I (2017) Prescribed burning is an effective and quick method to conserve rare pyrophilous forest-dwelling flat bugs. Insect Conserv Div 10:32-41

Heikkala O, Seibold S, Koivula M, Martikainen P, Thorn S, Müller J, Kouki J (2016b) Retention forestry and prescribed burning result in functionally different saproxylic beetle assemblages than clear-cutting. For Ecol Manag 359:51-58

Heikkala O, Suominen M, Junninen K, Hämäläinen A, Kouki J (2014) Effects of retention level and fire on retention tree dynamics in boreal forests. For Ecol Manag 328:193-201

Heliölä J, Koivula M, Niemelä J (2001) Distribution of carabid beetles (Coleoptera, Carabidae) across a boreal forest-clearcut ecotone. Cons Biol 15:370-377

Henttonen H, Haukisalmi V, Pirkkalainen H, Niemelä J (1998) Ekologisten käytävien merkityksestä keskisuomalaisissa talousmetsissä. Metsäntutkimuslaitoksen Tiedonantoja 705:255-271 (in Finnish)

Hiron M, Jonsell M, Kubart A, Thor G, Schroeder M, Dahlberg A, Johansson V, Ranius T (2017) Consequences of bioenergy wood extraction for landscapelevel availability of habitat for dead wood-dependent organisms. J Environ Manag 198:33-42

Hjältén J, Hägglund R, Löfroth T, Roberge J-M, Dynesius M, Olsson J (2017b) Forest restoration by burning and gap cutting of voluntary set-asides yield distinct immediate effects on saproxylic beetles. Biodivers Conserv 26:1623-1640

Hjältén J, Joelsson K, Gibb H, Work T, Löfroth T, Roberge JM (2017a) Biodiversity benefits for saproxylic beetles with uneven-aged silviculture. For Ecol Manag 402:37-50

Hjältén J, Stenbacka F, Andersson J (2010) Saproxylic beetle assemblages on low stumps, high stumps and logs: implications for environmental effects of stump harvesting. For Ecol Manag 260:1149-1155 
Hyvärinen E (2006) Green-tree retention and controlled burning in restoration and conservation of beetle diversity in boreal forests. Doctoral thesis, University of Joensuu, Joensuu, p 55

Hyvärinen E, Juslén A, Kemppainen E, Uddström A, Liukko U-M (eds) (2019) The 2019 red list of Finnish species. Ministry of Environment and Finnish Environment Institute, Helsinki, p 703

Hyvärinen E, Kouki J, Martikainen P (2006) Fire and green-tree retention in conservation of red-listed and rare deadwood-dependent beetles in Finnish boreal forests. Conserv Biol 20:1711-1719

Hyvärinen E, Kouki J, Martikainen P (2009) Prescribed fires and retention trees help to conserve beetle diversity in managed boreal forests despite their transient negative effects on some beetle groups. Insect Conserv Div 2:93-105

Hyvärinen E, Kouki J, Martikainen P, Lappalainen H (2005) Short-term effects of controlled burning and green-tree retention on beetle (Coleoptera) assemblages in managed boreal forests. For Ecol Manag 212:315-332

Jalonen J, Vanha-Majamaa I (2001) Immediate effects of four different felling methods on mature boreal spruce forest understorey vegetation in southern Finland. For Ecol Manag 146:25-34

Joelsson K (2017) Uneven-aged silviculture as a management tool to mitigate biodiversity loss. A case study of beetles in boreal forests. Doctoral thesis, Sveriges Lantbruksuniversitet, Umeå, p 54

Joelsson K, Hjältén J, Gibb H (2018a) Forest management strategy affects saproxylic beetle assemblages: a comparison of even and uneven-aged silviculture using direct and indirect sampling. PLoS One 13:e0194905

Joelsson K, Hjältén J, Work T (2018b) Uneven-aged silviculture can enhance within stand heterogeneity and beetle diversity. J Env Manag 205:1-8

Joelsson K, Hjältén J, Work T, Gibb H, Roberge J-M, Löfroth T (2017) Uneven-aged silviculture can reduce negative effects of forest management on beetles. For Ecol Manag 391:436-445

Johansson T, Gibb H, Hilszczanski J, Pettersson RB, Hjältén J, Atlegrim O, Ball JP, Danell K (2006) Conservation-oriented manipulations of coarse woody debris affect its value as habitat for spruce-infesting bark and ambrosia beetles (Coleoptera: Scolytinae) in northern Sweden. Can J For Res 36:174-185

Johansson T, Hjältén J, Stenbacka F, Dynesius M (2010) Responses of eight boreal flat bug (Heteroptera: Aradidae) species to clear-cutting and forest fire. J Insect Conserv 14:3-9

Johnson S, Strengbom J, Kouki J (2014) Low levels of tree retention do not mitigate the effects of clearcutting on ground vegetation dynamics. For Ecol Manag 330:67-74

Jokela J, Juutilainen K, Korpela L, Kouki J, Kuntsi S, Koivula M, Siitonen J (2018) Cross-taxon congruence and relationships to stand characteristics of vascular plants, bryophytes, polyporous fungi and beetles in mature managed boreal forests. Ecol Indic 85:137-145

Jokela J, Siitonen J, Koivula M (2019) Short-term effects of selection, gap, patch and clear cutting on the beetle fauna in boreal spruce-dominated forests. For Ecol Manag 446:29-37

Jonsell M, Abrahamsson M, Widenfalk L (2019) Increasing influence of the surrounding landscape on saproxylic beetle communities over 10 years succession in dead wood. For Ecol Manag 440:267-284

Jonsell M, Hansson J (2011) Logs and stumps in clearcuts support similar saproxylic beetle diversity: implications for bioenergy harvest. Silva Fenn 45:1053-1064

Jonsell M, Schroeder M (2014) Proportions of saproxylic beetle populations that utilise clear-cut stumps in a boreal landscape - biodiversity implications for stump harvest. For Ecol Manag 334:313-320

Jonsell M, Schroeder M, Weslien J (2005) Saproxylic beetles in high stumps of spruce: fungal flora important for determining the species composition. Scand J For Res 20:54-62

Junninen K, Kouki J, Renvall P (2008) Restoration of natural legacies of fire in European boreal forests: an experimental approach to the effects on wood decaying fungi. Can J For Res 38:202-215

Kaila S (ed) (1998) Monimuotoisuus talousmetsän uudistamisessa -hankkeen väliraportit (MONTA-hanke). Metsätehon Raportti 62. www.metsateho.fi/wpcontent/uploads/2015/02/metsatehon_raportti_062.pdf (in Finnish) (Accessed 09 June 2019)

Kålås JA, Viken Å, Henriksen S, Skjelseth S (eds) (2010) The 2010 Norwegian red list for species. Norwegian Biodiversity Information Centre, Norway, p 480

Karlsson K (2008) Long-term field experiments in Forest research. In: Proceedings from a NoLTFoX meeting in Scotland, 5th to 6th of June, 2008, vol 105. Working papers of the Finnish Forest research institute, Vantaa, p 47
Kärvemo S, Björkman C, Johansson T, Weslien J, Hjältén J (2017) Forest restoration as a double-edged sword: the conflict between biodiversity conservation and pest control. J Appl Ecol 54:1658-1668

Koivula M (2001) Carabid beetles (Coleoptera, Carabidae) in boreal managed forests - meso-scale ecological patterns in relation to modern forestry, vol 22. Doctoral thesis, University of Helsinki, Helsinki

Koivula M (2002a) Alternative harvesting methods and boreal carabid beetles (Coleoptera, Carabidae). For Ecol Manag 167:103-121

Koivula M (2002b) Boreal carabid-beetle (Coleoptera, Carabidae) assemblages in thinned uneven-aged and clear-cut spruce stands. Ann Zool Fenn 39: $131-149$

Koivula M, Kuuluvainen T, Hallman E, Kouki J, Siitonen J, Valkonen S (2014) Forest management inspired by natural disturbance dynamics (DISTDYN) - a longterm research and development project in Finland. Scand J For Res 29:579-592

Koivula M, Niemelä J (2003) Gap felling as a forest harvesting method in boreal forests: responses of carabid beetles (Coleoptera, Carabidae). Ecography 26: 179-187

Koivula MJ (2012) Under which conditions does retention harvesting support ground beetles of boreal forests? Baltic J Coleopterology 12:7-26

Koivula MJ, Venn S, Hakola P, Niemelä J (2019) Responses of boreal ground beetles (Coleoptera, Carabidae) to different logging regimes ten years postharvest. For Ecol Manag 436:27-38

Komonen A, Kuntsi S, Toivanen T, Kotiaho JS (2014) Fast but ephemeral effects of ecological restoration on forest beetle community. Biodivers Conserv 23: 1485-1507

Kontula T, Raunio A (eds) (2018). Suomen luontotyyppien uhanalaisuus 2018. Luontotyyppien punainen kirja. Suomen Ympäristö 5/2018. 1313 pp (in Finnish)

Korhonen KT, Auvinen A-P, Kuusela S, Punttila P, Salminen O, Siitonen J, Ahlroth $P$, Jäppinen J-P, Kolström T (2016) Biotalousskenaarioiden mukaisten hakkuiden vaikutukset metsien monimuotoisuudelle tärkeisiin rakennepiirteisiin. Luonnonvara- ja biotalouden tutkimus 51/2016: 1-36 (in Finnish)

Kotiaho JS, Kuusela S, Nieminen E, Päivinen J (eds) (2015) Elinympäristöjen tilan edistäminen Suomessa. ELITE-työryhmän mietintö elinympäristöjen tilan edistämisen priorisointisuunnitelmaksi ja arvio suunnitelman kokonaiskustannuksista. Suomen Ympäristö 8/2015. 246 pp (in Finnish)

Kouki J (2019) Fire and retention trees in facilitating biodiversity in boreal forests. forest.uef.fi/jarikouki/project fire.htm (Accessed 09 June 2019)

Kouki J, Hyvärinen E, Lappalainen H, Martikainen P, Similä M (2012) Landscape context affects the success of habitat restoration: large-scale colonization patterns of saproxylic and fire-associated species in boreal forests. Diver Distr 18:348-355

Kruys N, Fridman J, Götmark F, Simonsson P, Gustafsson L (2013) Retaining trees for conservation at clearcutting has increased structural diversity in young Swedish production forests. For Ecol Manag 304:312-321

Kuuluvainen T, Lindberg H, Vanha-Majamaa I, Keto-Tokoi P, Punttila P (2019) Lowlevel retention forestry, certification and biodiversity: case Finland. Ecol Process 8:47

Lee SI, Spence JR, Langor DW (2017) Combinations of aggregated and dispersed retention improve conservation of saproxylic beetles in boreal white spruce stands. For Ecol Manag 385:116-126

Lencinas MV, Martinez Pastur G, Solán R, Gallo E, Cellini JM (2008) Forest management with variable retention impact over bryophyte communities of Nothofagus pumilio understory. Forstarchiv 79:77-82

Lilja S, De Chantal M, Kuuluvainen T, Vanha-Majamaa I, Puttonen P (2005) Restoring natural characteristics in managed Norway spruce [Picea abies (L.) Karst.] stands with partial cutting, dead wood creation and fire: immediate treatment effects. Scand J For Res 20:68-78

Lindberg H, Punttila P, Vanha-Majamaa I (2020) The challenge of combining variable retention and prescribed burning in Finland. Ecol Process. https:// doi.org/10.1186/s13717-019-0207-3

Lindbladh M, Abrahamsson M (2008) Beetle diversity in high-stumps from Norway spruce thinnings. Scand J For Res 23:339-347

Lindbladh M, Abrahamsson M, Seedre M, Jonsell M (2007) Saproxylic beetles in artificially created high-stumps of spruce and birch within and outside hotspot areas. Biodivers Conserv 16:3213-3226

Lindhe A, Åsenblad N, Toresson H-G (2004) Cut logs and high stumps of spruce, birch, aspen and oak - nine years of saproxylic fungi succession. Biol Conserv 119:443-454

Lindhe A, Lindelöw A (2004) Cut high stumps of spruce, birch, aspen and oak as breeding substrates for saproxylic beetles. For Ecol Manag 203:1-20 
Lõhmus P, Leppik E, Motiejunaite J, Suija A, Lõhmus A (2012) Old selectively cut forests can host rich lichen communities-lessons from an exhaustive field survey. Nova Hedwigia 95:493-515

Lõhmus P, Lõhmus A, Hämäläinen A (2018) Rapid legacy-dependent succession of lichen assemblages after forest fires: insights from two boreal regions. J Veg Sci 29:200-212

Martikainen P (2000) Effects of forest management on beetle diversity, with implications for species conservation and forest protection. Doctoral thesis, University of Joensuu, Joensuu, p 50

Martikainen P, Kouki J, Heikkala O (2006a) The effects of green tree retention and subsequent prescribed burning on ground beetles (Coleoptera: Carabidae) in boreal pine-dominated forests. Ecography 29:659-670

Martikainen P, Kouki J, Heikkala O, Hyvärinen E, Lappalainen H (2006b) Effects of green tree retention and prescribed burning on the crown damage caused by the pine shoot beetles (Tomicus spp.) in pine-dominated timber harvest areas. J Appl Entomol 130:37-44

Matveinen-Huju K (2007) Short-term effects of variable retention on epigaeic spiders and carabid beetles in Finland. Doctoral thesis, University of Helsinki, Helsinki, p 39

Matveinen-Huju K, Koivula M (2008) Effects of alternative harvesting methods on boreal forest spider assemblages. Can J For Res 38:782-794

Matveinen-Huju K, Koivula M, Niemelä J, Rauha AM (2009) Short-term effects of retention felling at mire sites on boreal spiders and carabid beetles. For Ecol Manag 258:2388-2398

Matveinen-Huju K, Niemelä J, Rita H, O'Hara RB (2006) Retention-tree groups in clear-cuts: do they constitute 'life-boats' for spiders and carabids? For Ecol Manag 230:119-135

Nelson CR, Halpern CB (2005) Edge-related responses of understory plants to aggregated retention harvest in the Pacific northwest. Ecol Appl 15:196-209

Niemelä J, Koivula M, Kotze DJ (2007) The effects of forestry on carabid beetles (Coleoptera: Carabidae) in boreal forests. J Insect Conserv 11:5-18

Nordén B, Götmark F, Ryberg M, Paltto H, Allmér J (2008) Partial cutting reduces species richness of fungi on woody debris in oak-rich forests. Can J For Res 38:1807-1816

Nordén B, Paltto H, Claesson C, Götmark F (2012) Partial cutting can enhance epiphyte conservation in temperate oak-rich forests. For Ecol Manag 270:35-44

Økland B, Götmark F, Nordén N (2008) Oak woodland restoration: testing the effects on biodiversity by mycetophilids in southern Sweden. Biodivers Conserv 17:2599

Oldén A, Selonen VAO, Lehkonen E, Kotiaho JS (2019a) The effect of buffer strip width and selective logging on streamside plant communities. BMC Ecol 19:9

Oldén A, Selonen VAO, Lehkonen E, Kotiaho JS (2019a) The effect of buffer strip width and selective logging on streamside plant communities. BMC Ecol 19(1):9

Olsson J, Jonsson BG, Hjältén J, Ericson L (2011) Addition of coarse woody debris - the early fungal succession on Picea abies logs in managed forests. Biol Conserv 144:1100-1110

Paltto H, Nordén B, Götmark F (2008) Partial cutting as a conservation alternative for oak (Quercus spp.) forest - responses of bryophytes and lichens on dead wood. For Ecol Manag 256:536-547

Pasanen H (2017) Ecological effects of disturbance-based restoration in boreal forests. Doctoral thesis, University of Eastern Finland, Joensuu, p 29

Pasanen H, Juutilainen K, Siitonen J (2019) Responses of polypore fungi following disturbance-emulating harvesting treatments and deadwood creation in boreal Norway spruce dominated forests. Scand J For Res https://doi.org/10. 1080/02827581.2019.1663915

Pasanen H, Junninen K, Kouki J (2014) Restoring dead wood in forests diversifies wood-decaying fungal assemblages but does not quickly benefit red-listed species. For Ecol Manag 312:92-100

Pasanen H, Juutilainen K, Siitonen J (2019) Responses of polypore fungi following disturbance-emulating harvesting treatments and deadwood creation in boreal Norway spruce dominated forests. Scand J For Res. https://doi.org/10. 1080/02827581.2019.1663915

Penttilä R, Junninen K, Punttila P, Siitonen J (2013) Effects of forest restoration by fire on polypores depends strongly on time since disturbance-a case study from Finland based on a 23-year monitoring period. For Ecol Manag 310:508-516

Penttilä R, Kotiranta H (1996) Short-term effects of prescribed burning on woodrotting fungi. Silva Fenn 30:399-419

Perhans K, Appelgren L, Jonsson F, Nordin U, Söderström B, Gustafsson L (2009) Retention patches as potential refugia for bryophytes and lichens in managed forest landscapes. Biol Conserv 142:1125-1133
Persson T, Egnell G (2018) Stump harvesting for bioenergy: a review of climatic and environmental impacts in northern Europe and America. Wiley Interdiscip Rev Energy Environ 7:e307

Pietikäinen AS, Haimi J, Siitonen J (2003) Short-term responses of soil macroarthropod community to clear felling and alternative forest regeneration methods. For Ecol Manag 172:339-353

Pihlaja M, Koivula M, Niemelä J (2006) Responses of boreal carabid beetle assemblages (Coleoptera, Carabidae) to clear-cutting and top-soil preparation. For Ecol Manag 222:182-190

Pitkänen A, Kouki J, Viiri H, Martikainen P (2008) Effects of controlled forest burning and intensity of timber harvesting on the occurrence of pine weevils, Hylobius spp., in regeneration areas. For Ecol Manag 255:522-529

Pitkänen A, Törmänen K, Kouki J, Järvinen E, Viiri H (2005) Effects of green tree retention, prescribed burning and soil treatment on pine weevil (Hylobius abietis and Hylobius pinastri) damage to planted Scots pine seedlings. Agr For Entomol 7:319-331

Rabinowitsch-Jokinen R, Laaka-Lindberg S, Vanha-Majamaa I (2012) Immediate effects of logging, mounding and removal of logging residues on epixylic species in managed boreal Norway spruce stands in southern Finland. J Sust For 31:205-229

Rabinowitsch-Jokinen R, Vanha-Majamaa I (2010) Immediate effects of logging, mounding and removal of logging residues and stumps on coarse woody debris in managed boreal Norway spruce stands. Silva Fenn 44:51-61

Ranius T, Hämäläinen A, Egnell G, Olsson B, Eklöf K, Stendahl J, Rudolphi J, Stens A, Felton A (2018) The effects of logging residue extraction for energy on ecosystem services and biodiversity: a synthesis. J Env Manag 209:409-425

Ranlund ̊̊, Hylander K, Johansson V, Jonsson F, Nordin U, Gustafsson L (2018) Epiphytic lichen responses to environmental change due to clear-cutting differ among tree taxa. J Veg Sci 29:1065-1074

Ranlund $\AA$, Victorsson J (2018) Stump extraction in the surrounding landscape: predatory saproxylic beetles are more negatively affected than lower trophic levels. For Ecol Manag 408:75-86

Reinikainen A, Mäkipää R, Vanha-Majamaa I, Hotanen JP (eds) (2000) Kasvit muuttuvassa metsäluonnossa. Tammi, Jyväskylä (in Finnish)

Rheault H, Drapeau P, Bergeron Y, Esseen P-A (2003) Edge effects on epiphytic lichen in managed black spruce forest of eastern North America. Can J For Res 33:23-32

Rodriguez A, Kouki J (2015) Emulating natural disturbance in forest management enhances pollination services for dominant Vaccinium shrubs in boreal pinedominated forests. For Ecol Manag 350:1-12

Rodriguez A, Kouki J (2017) Disturbance-mediated heterogeneity drives pollinator diversity in boreal managed forest ecosystems. Ecol Appl 27:589-602

Rodriguez Olmo A (2018) Promoting biodiversity and ecosystem services in managed boreal forests through disturbance-mediated functional heterogeneity. Doctoral thesis, University of Eastern Finland, Joensuu, p 42

Rudolphi J, Caruso A, von Cräutlein M, Laaka-Lindberg S, Ryömä R, Berglund H (2011) Relative importance of thinned and clear-cut stands for bryophyte diversity on stumps. For Ecol Manag 261:1911-1918

Salo K, Domisch T, Kouki J (2019) Forest wildfire and 12 years of post-disturbance succession of saprotrophic macrofungi (Basidiomycota, Ascomycota). For Ecol Manag 451:117454

Sandström J, Bernes C, Junninen K, Lõhmus A, Macdonald E, Müller J, Jonsson BG (2019) Impacts of dead wood manipulation on the biodiversity of temperate and boreal forests: a systematic review. J Appl Ecol 56:1770-1781

Santaniello F (2017) Impact of tree retention on wood production, biodiversity conservation and carbon stock changes in boreal pine forest. Doctoral thesis, Sveriges Lantbruksuniversitet, Uppsala, p 74

Santaniello F, Djupström LB, Ranius T, Rudolphi J, Widenfalk O, Weslien J (2016) Effects of partial cutting on logging productivity, economic returns and dead wood in boreal pine forest. For Ecol Manag 365:152-158

Santaniello F, Djupström LB, Ranius T, Weslien J, Rudolphi J, Sonesson J (2017b) Simulated long-term effects of varying tree retention on wood production, dead wood and carbon stock changes. J Environ Manag 201:37-44

Santaniello F, Djupström LB, Ranius T, Weslien J, Rudolphi J, Thor G (2017a) Large proportion of wood dependent lichens in boreal pine forest are confined to old hard wood. Biodivers Conserv 26:1295-1310

Scott RE, Neyland MG, Baker SC (2019) Variable retention in Tasmania, Australia: trends over 16 years of monitoring and adaptive management. Ecol Process $8: 23$

Selonen V (2014) Forest act habitats. Finnish woodland key habitats amid the intensive forestry. Doctoral thesis, University of Jyväskylä, Jyväskylä 
Selonen VAO, Kotiaho J (2013) Buffer strips can pre-empt extinction debt in boreal streamside habitats. BMC Biol 13:24

Selonen VAO, Mussaari M, Toivanen T, Kotiaho JS (2011) The conservation potential of brook-side key habitats in managed boreal forests. Silva Fenn 45:1041-1052

Shorohova E, Sinkevich S, Kryshen A, Vanha-Majamaa I (2019) Variable retention forestry in European boreal forests in Russia. Ecol Process 8:34

Sidoroff K, Kuuluvainen T, Tanskanen H, Vanha-Majamaa I (2007) Tree mortality after low-intensity prescribed fires in managed Pinus sylvestris stands in southern Finland. Scand J For Res 22:2-12

Siira-Pietikäinen A (2002) Decomposer community in boreal coniferous forest soil after forest harvesting. Doctoral thesis, University of Jyväskylä, Jyväskylä, p 50

Siira-Pietikäinen A, Haimi J (2009) Changes in soil fauna 10 years after forest harvestings: comparison between clear felling and green-tree retention methods. For Ecol Manag 258:332-338

Siira-Pietikäinen A, Pietikäinen JM, Fritze H, Haimi J (2001) Short-term responses of soil decomposer communities to forest management: clear felling versus alternative forest harvesting methods. Can J For Res 31:88-99

Siitonen J (2001) Forest management, coarse woody debris and saproxylic organisms: Fennoscandian boreal forests as an example. Ecol Bull 49:1-41

Siitonen J, Saaristo L (2000) Habitat requirements and conservation of Pytho kolwensis, a beetle species of old-growth boreal forest. Biol Conserv 94:211-220

Similä M, Kouki J, Martikainen P (2003) Saproxylic beetles in managed and seminatural Scots pine forests: quality of dead wood matters. For Ecol Manag 174:365-381

Sippola A-L, Similä M, Mönkkönen M, Jokimäki J (2004) Diversity of polyporous fungi (polyporaceae) in northern boreal forests: effects of forest site type and logging intensity. Scand J For Res 19:152-163

Stokland JN, Siitonen J, Jonsson BG (2012) Biodiversity in dead wood. Cambridge University Press, Cambridge, p 507

Storaunet KO, Rolstad J, Rolstad E (2014) Effects of logging on the threatened epiphytic lichen Usnea longissima: an experimental approach. Silva Fenn 48: 685-703

Storaunet KO, Rolstad J, Toeneiet M, Rolstad E (2008) Effect of logging on the threatened epiphytic lichen Usnea longissima: a comparative and retrospective approach. Silva Fenn 42:685-703

Suominen M (2018) Harvested and burned forests as habitats for polypore fungi. Doctoral thesis, University of Eastern Finland, Joensuu, p 23

Suominen M, Junninen K, Heikkala O, Kouki J (2015) Combined effects of retention forestry and prescribed burning on polypore fungi. J Appl Ecol 52: $1001-1008$

Suominen M, Junninen K, Heikkala O, Kouki J (2018) Burning harvested sites enhances polypore diversity on stumps and slash. For Ecol Manag 414:47-53

Suominen M, Junninen K, Kouki J (2019) Diversity of fungi in harvested forests 10 years after logging and burning: polypore assemblages on different woody substrates. For Ecol Manag 446:63-70

Sverdrup-Thygeson A, Ims RA (2002) The effect of forest clearcutting in Norway on the community of saproxylic beetles on aspen. Biol Conserv 106:347-357

Thorn S, Seibold S, Heikkala O, Koivula M, Venugopal P, Kouki J (2018) New records of Northern bats (Eptesicus nilssonii) in boreal clear cuts emphasize the value of green-tree retention for conservation. Nyctalus 19:22-26

Timonen J (2011) Woodland key habitats. A key to effective conservation of forest biodiversity? Doctoral thesis, University of Jyväskylä, Jyväskylä, p 44

Toivanen T (2007) Short-term effects of forest restoration on beetle diversity. Doctoral thesis, University of Jyväskylä, Jyväskylä, p 36

Toivanen T, Selonen V, Kotiaho JS (2004) Effects of management and restoration on forest biodiversity: an experimental approach. EFI Proceedings No. 51: 493-503.

Toivanen T, Heikkilä T, Koivula MJ (2014) Emulating natural disturbances in boreal Norway spruce forests: effects on ground beetles (Coleoptera, Carabidae). For Ecol Manag 314:64-74

Toivanen T, Kotiaho J (2007a) Mimicking natural disturbances of boreal forests: the effects of controlled burning and creating dead wood on beetle diversity. Biodivers Conserv 16:3193-3211

Toivanen T, Kotiaho J (2010) The preferences of saproxylic beetle species for different dead wood types created in forest restoration treatments. Can J For Res 40:445-464

Toivanen T, Kotiaho JS (2007b) Burning of logged sites to protect beetles in managed boreal forests. Cons Biol 21:1562-1572

Toivanen T, Liikanen V, Kotiaho JS (2009) Effects of forest restoration treatments on the abundance of bark beetles in Norway spruce forests of southern Finland. For Ecol Manag 257:117-125
Tonteri T, Salemaa M, Rautio P, Hallikainen V, Korpela L, Merilä P (2016) Forest management regulates temporal change in the cover of boreal plant species. For Ecol Manag 381:115-124

Tullus T, Rosenvald R, Leis M, Lõhmus P (2018) Impacts of shelterwood logging on forest bryoflora: Distinct assemblages with richness comparable to mature forests. For Ecol Manag 411:67-74

Tullus T, Tishler M, Rosenvald R, Tullus A, Lutter R, Tullus H (2019) Early responses of vascular plant and bryophyte communities to uniform shelterwood cutting in hemiboreal scots pine forests. For Ecol Manag 440:70-78

Vanha-Majamaa I, Hautala H (2010) Effect of the size of retention tree groups on biodiversity in forest regeneration (RETREE). Natural Resources Institute Finland (LUKE) www.metla.fi/hanke/8532/pdf/RETREE_methods.pdf (Accessed 09 June 2019)

Vanha-Majamaa I, Jalonen J (2001) Green tree retention in Fennoscandian forestry. Scand J For Res (Suppl 3):79-90

Vanha-Majamaa I, Lilja S, Ryömä R, Kotiaho JS, Laaka-Lindberg S, Lindberg H, Puttonen P, Tamminen P, Toivanen T, Kuuluvainen T (2007) Rehabilitating boreal forest structure and species composition in Finland through logging, dead wood creation and fire: the EVO experiment. For Ecol Manag 250:77-88

Vanha-Majamaa I, Shorohova E, Kushnevskaya H, Jalonen J (2017) Resilience of understory vegetation after variable retention felling in boreal Norway spruce forests: a ten-year perspective. For Ecol Manag 393:12-28

Varenius K, Karen O, Lindahl B, Dahlberg A (2016) Long-term effects of tree harvesting on ectomycorrhizal fungal communities in boreal Scots pine forests. For Ecol Manag 380:41-49

Victorsson J, Jonsell M (2013) Ecological traps and habitat loss, stump extraction and its effects on saproxylic beetles. For Ecol Manag 290:22-29

Victorsson J, Jonsell M (2014) Effects of stump extraction on saproxylic beetle diversity in Swedish clear-cuts. Insect Conserv Div 6:483-493

Wallenius TH, Kuuluvainen T, Vanha-Majamaa I (2004) Fire history in relation to site type and vegetation in Vienansalo wilderness in eastern Fennoscandia, Russia. Can J For Res 34:1400-1409

Wikars LO (1995) Clear-cutting before burning prevents establishment of the fireadapted Agonum quadripunctatum (Coleoptera: Carabidae). Ann Zool Fenn 32:375-384

Work TT, Andersson J, Ranius T, Hjältén J (2016) Defining stump harvesting retention targets required to maintain saproxylic beetle biodiversity. For Ecol Manag 371:90-102

Ylisirniö AL, Hallikainen V (2018) Retention patches maintain diversity of epiphytic and epixylic indicator lichens more effectively than solitary trees. Scand J For Res 33:320-331

\section{Publisher's Note}

Springer Nature remains neutral with regard to jurisdictional claims in published maps and institutional affiliations.

\section{Submit your manuscript to a SpringerOpen ${ }^{\circ}$ journal and benefit from:}

- Convenient online submission

- Rigorous peer review

- Open access: articles freely available online

High visibility within the field

- Retaining the copyright to your article

Submit your next manuscript at $>$ springeropen.com 